\title{
Ancestral Caddo Ceramic Vessels from Sites in the Upper Neches River Basin in Anderson and Cherokee Counties, Texas
}

Timothy K. Perttula

Heritage Research Center, Stephen F. Austin State University

Julian A. Sitters

Texas Historical Commission

Follow this and additional works at: https://scholarworks.sfasu.edu/ita

Part of the American Material Culture Commons, Archaeological Anthropology Commons, Environmental Studies Commons, Other American Studies Commons, Other Arts and Humanities Commons, Other History of Art, Architecture, and Archaeology Commons, and the United States History Commons

Tell us how this article helped you.

This Article is brought to you for free and open access by the Center for Regional Heritage Research at SFA ScholarWorks. It has been accepted for inclusion in Index of Texas Archaeology: Open Access Gray Literature from the Lone Star State by an authorized editor of SFA ScholarWorks. For more information, please contact cdsscholarworks@sfasu.edu. 


\section{Ancestral Caddo Ceramic Vessels from Sites in the Upper Neches River Basin in Anderson and Cherokee Counties, Texas}

\section{Creative Commons License}

\section{(c) (1) (8)}

This work is licensed under a Creative Commons Attribution-NonCommercial 4.0 International License 


\title{
Ancestral Caddo Ceramic Vessels from Sites in the Upper Neches River Basin in Anderson and Cherokee Counties, Texas
}

\author{
Timothy K. Perttula and Julian A. Sitters
}

\section{Introduction}

Late Caddo period sites belonging to the Frankston phase (ca. A.D. 1400-1680) and the Historic Caddo Allen phase (ca. A.D. 1680-1800) are common in the upper Neches River basin in East Texas (Figure 1), including habitation sites as well as associated and unassociated cemeteries. As is well known, ancestral Caddo cemeteries have burial features with associated funerary offerings, most commonly ceramic vessels (see Perttula et al. 2011:403-433). In this article, we document 34 ancestral Caddo ceramic vessels in the collections of the Texas Archeological Research Laboratory at The University of Texas at Austin (TARL) from six different sites in the upper Neches River basin, including the Ballard Estates (41AN53, n=4 vessels), O. L. Ellis (41AN54, n=15), Lee Ellis (41AN56, n=1), Dabbs Estate (41AN57, n=3), A. H. Reagor (41CE15, n=3), and John Bragg (41CE23, n=8 vessels) sites.

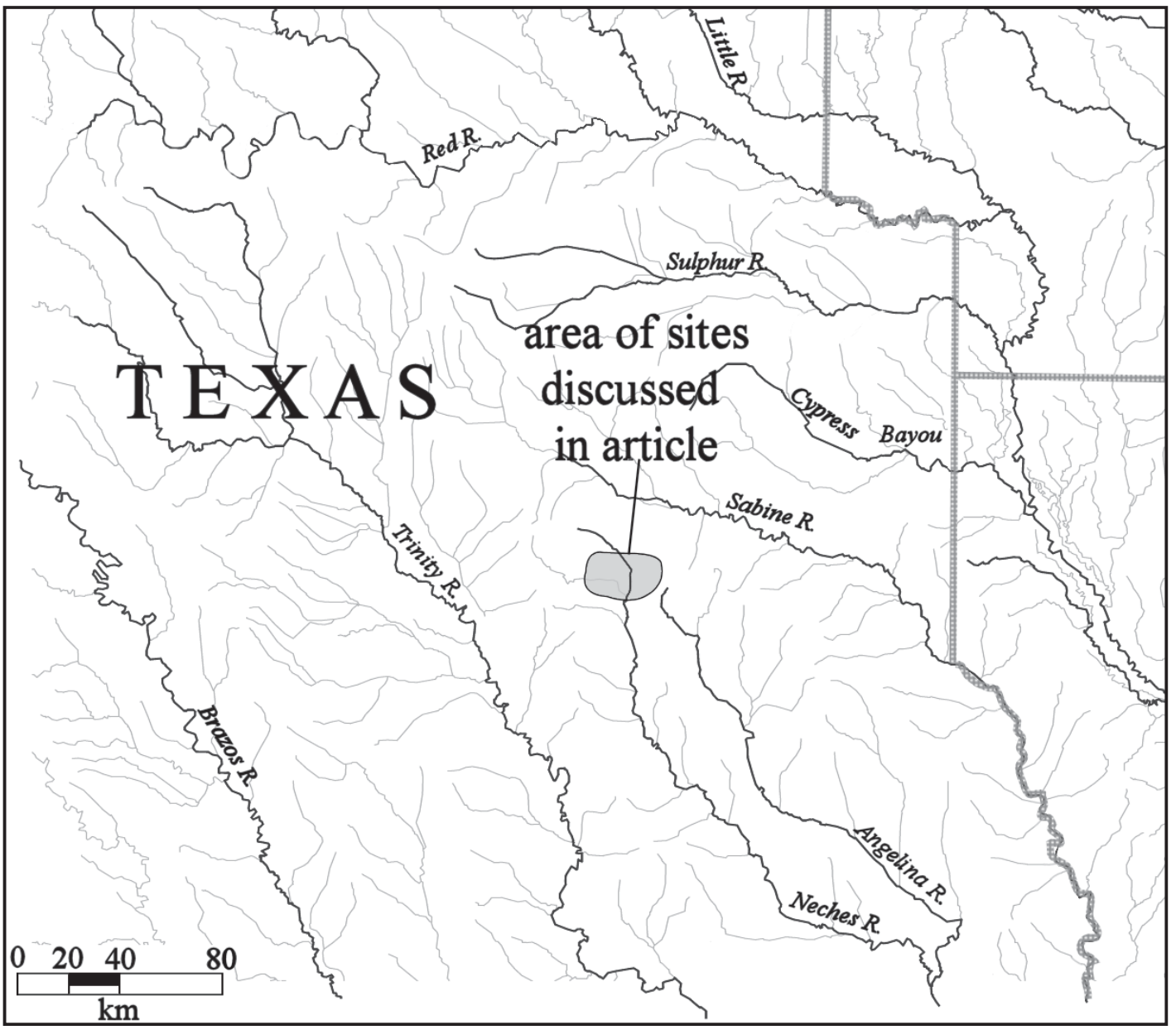

Figure 1. Location of Caddo sites in East Texas discussed in this article. 
Our first purpose is to put on record these ceramic vessels from six poorly known ancestral Caddo sites in order to better understand the history of Caddo settlement in the upper Neches River basin, including the history of burial interments at these sites.

The second purpose is much broader, and is part of an effort to establish an East Texas Caddo ceramic vessel database that can be employed for a variety of research purposes. The synthesis of the stylistically diverse Caddo ceramic wares in different recognized ancestral communities across the Caddo area, including the upper Neches River basin occupied by a Hasinai Caddo group, would seem to be tailor-made for studies of ancestral Caddo social networks and social identities that rely on large regional ceramic datasets (see Collar et al. 2015; Mills et al. 2015; Hart 2016). The formal and statistical assessment of the regional variation in Caddo ceramic assemblages is currently being assembled in a Geographic Information System by Robert Z. Selden, Jr. (Stephen F. Austin State University), and the assemblages include the vessels from the six sites discussed herein. This is based on the delineation of temporal and spatial divisions in the character of Caddo ceramics (i.e., principally data on decorative methods, vessel forms, defined types and varieties, and the use of different tempers) across East Texas sites and other parts of the Caddo area, and then constructing networks of similarities between ceramic assemblages from these sites (cf. Peeples and Roberts 2013:3003-3004) that can be used to assess the strength of cultural and social relationships among Caddo communities in the region through time and across space. The identification of such postulated relationships can then be explored to determine the underlying reasons for the existence of such relationships, including factors such as the frequency of interaction and direct contact between communities, the trade and exchange of ceramic vessels, population movement, and similarities in the organization of ceramic vessel production. In conjunction with a database on 2D/3D-scanned Caddo ceramic vessels from East Texas sites, the East Texas Caddo ceramic vessel database is made part of a digital database where comprehensive mathematical and quantitative analyses of morphological attributes and decorative elements on vessels can be conducted (e.g., Smith et al. 2014). Queries to such a combined database of vessels and sherds should lead to better understandings of regional Caddo ceramic stylistic and technological attributes and their spatial and temporal underpinnings.

The results of past and current instrumental neutron activation analysis (INAA) and petrographic analysis of Caddo Area ceramics, including East Texas (where there is a robust INAA database) can also be explored as a means to corroborate production locales (cf. Selden et al. 2014), and establish the chemical and paste characteristics of local fine ware and utility ware ceramics in assemblages of different ages. These in turn allow the evaluation of the possible movement of ceramic vessels between different Caddo communities in East Texas and the broader Caddo world.

\section{Ballard Estates Site (41AN53)}

The collections from the Ballard Estates site have four ancestral Caddo ceramic fine ware vessels from a Late Caddo period, Frankston phase, context. They include one carinated bottle and three globular carinated bowls. These vessels were obtained from two burials excavated by University of Texas (UT) archaeologists in 1935. Associated with the burials were four generally contemporaneous habitation areas from ca. 130-470 m distance from the burial area.

SITE NAME OR SITE NUMBER: Ballard Estates

VESSEL NO.: 1

VESSEL FORM: Carinated bottle

NON-PLASTICS AND PASTE: grog 
RIM AND LIP FORM: Direct rim, but broken lip

CORE COLOR: $\mathrm{F}$ (fired in a reducing environment and cooled in the open air)

INTERIOR SURFACE COLOR: yellowish-brown

EXTERIOR SURFACE COLOR: yellowish-brown; fire clouds on the rim, body, and base

WALL THICKNESS (IN MM): neck, $6.3 \mathrm{~mm}$

INTERIOR SURFACE TREATMENT: none

EXTERIOR SURFACE TREATMENT: burnished

HEIGHT (IN CM): 14.3+

ORIFICE DIAMETER (IN CM): 16.1 (on the body)

DIAMETER AT BOTTOM OF RIM OR NECK (IN CM): 6.6

BASE DIAMETER (IN CM) AND SHAPE OF BASE: 7.2; circular and flat

ESTIMATED VOLUME (IN LITERS): 0.41+

DECORATION (INCLUDING MOTIF AND ELEMENTS WHEN APPARENT): The upper body panel is defined by upper and lower horizontal engraved lines. The panel is divided into four rectangular sections that have negative petal- and oval-shaped elements outlined by diagonal hatched or crosshatched areas (Figure 2a). Three of the sections have four-leafed petals, and the other has a seven-leafed petal-shaped element.

The lower vessel body also has an engraved panel defined by upper and lower horizontal engraved lines. The panel is divided by seven vertical bracket elements filled with diagonal and diagonal opposed hatched lines (Figure 2b). These decorative elements are consistent with those identified on Poynor Engraved, var. Hood carinated bowls (Perttula 2011:Figure 6-64e).

PIGMENT USE AND LOCATION ON VESSEL: none

TYPE AND VARIETY (IF KNOWN): Poynor Engraved, var. unspecified

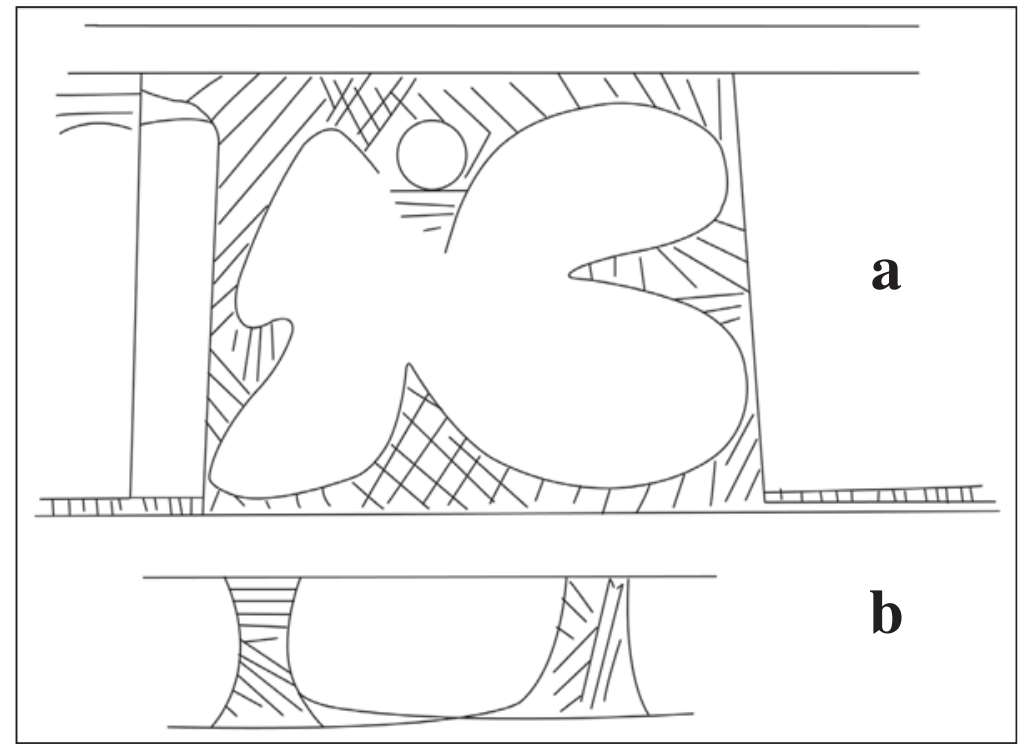

Figure 2. Decorative elements on Poynor Engraved, var. unspecified bottle (Vessel 1) from the Ballard Estates site (41AN53): a, upper vessel body; $b$, lower vessel body. 
SITE NAME OR SITE NUMBER: Ballard Estates (41AN53)

VESSEL NO.: 2

VESSEL FORM: Carinated bowl

NON-PLASTICS AND PASTE: grog

RIM AND LIP FORM: Inverted rim and rounded lip

CORE COLOR: F (fired in a reducing environment and cooled in the open air)

INTERIOR SURFACE COLOR: yellowish-brown; fire clouds on the body

EXTERIOR SURFACE COLOR: yellowish-brown; fire clouds on the rim, body, and base, including pink fire clouds (i.e., pinkware)

WALL THICKNESS (IN MM): rim, $7.1 \mathrm{~mm}$

INTERIOR SURFACE TREATMENT: smoothed

EXTERIOR SURFACE TREATMENT: smoothed

HEIGHT (IN CM): 11.1

ORIFICE DIAMETER (IN CM): 14.2

DIAMETER AT BOTTOM OF RIM OR NECK (IN CM): 18.2

BASE DIAMETER (IN CM) AND SHAPE OF BASE: 9.3; circular and flat

ESTIMATED VOLUME (IN LITERS): 1.1

DECORATION (INCLUDING MOTIF AND ELEMENTS WHEN APPARENT): The rim is divided into four alternating oval-shaped and diamond-shaped engraved elements (Figure 3) Each of the diamondshaped elements is defined by two upper and two lower triangular-shaped corners with interior diamondshaped elements.

PIGMENT USE AND LOCATION ON VESSEL: none

TYPE AND VARIETY (IF KNOWN): Poynor Engraved, var. N’ (Perttula 2011:Figure 6-65)

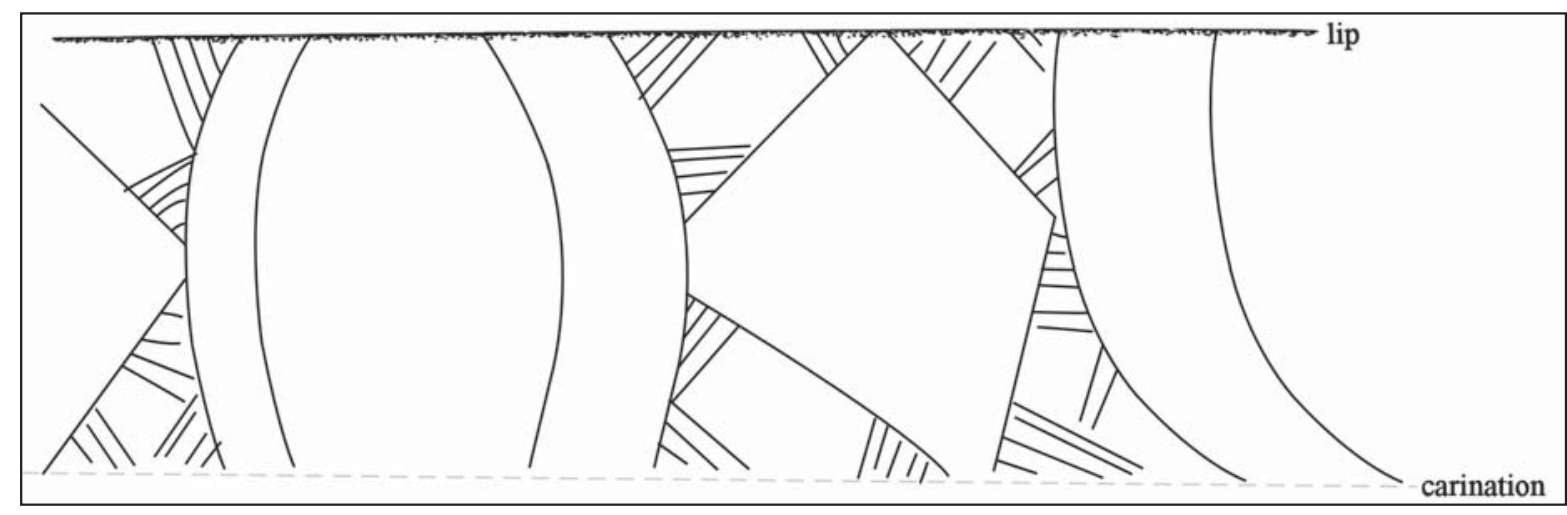

Figure 3. Decorative elements on Poynor Engraved, var. N' carinated bowl (Vessel 2) from the Ballard Estates site (41AN53). 
SITE NAME OR SITE NUMBER: Ballard Estates (41AN53)

VESSEL NO.: 3

VESSEL FORM: Carinated bowl

NON-PLASTICS AND PASTE: grog and hematite

RIM AND LIP FORM: Direct rim and rounded lip

CORE COLOR: F (fired in a reducing environment and cooled in the open air)

INTERIOR SURFACE COLOR: reddish-brown; fire clouds on the base

EXTERIOR SURFACE COLOR: yellowish-brown; fire clouds on the rim, body, and base

WALL THICKNESS (IN MM): rim, $6.4 \mathrm{~mm}$

INTERIOR SURFACE TREATMENT: smoothed

EXTERIOR SURFACE TREATMENT: smoothed

HEIGHT (IN CM): 9.3

ORIFICE DIAMETER (IN CM): 16.5

DIAMETER AT BOTTOM OF RIM OR NECK (IN CM): 9.3

BASE DIAMETER (IN CM) AND SHAPE OF BASE: 8.2; circular and flat

ESTIMATED VOLUME (IN LITERS): 0.92

DECORATION (INCLUDING MOTIF AND ELEMENTS WHEN APPARENT): The rim is divided into seven rectangular panels by sets of two closely-spaced vertical engraved lines with upper and lower hatched triangle elements (Figure 4). The center of each of the panels has an engraved circle element filled with excised linear punctations.

PIGMENT USE AND LOCATION ON VESSEL: none

TYPE AND VARIETY (IF KNOWN): Poynor Engraved, var. Blackburn (Perttula 2011:Figure 6-64b')

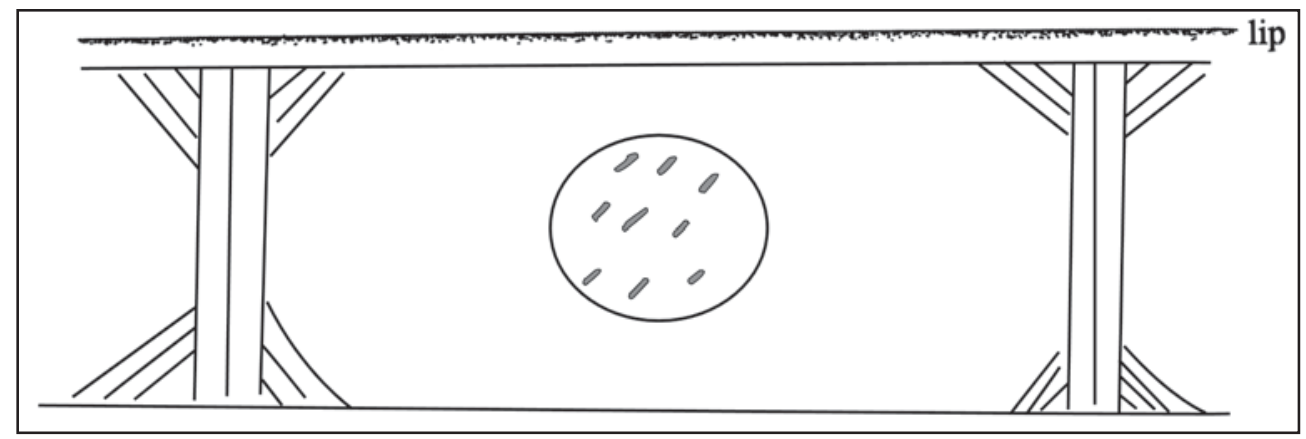

Figure 4. Decorative elements on Poynor Engraved, var. Blackburn carinated bowl (Vessel 3) from the Ballard Estates site (41AN53). 
SITE NAME OR SITE NUMBER: Ballard Estates (41AN53)

VESSEL NO.: 4

VESSEL FORM: Globular carinated bowl

NON-PLASTICS AND PASTE: grog

RIM AND LIP FORM: Everted rim and rounded lip; 10 small rim peaks

CORE COLOR: Unknown

INTERIOR SURFACE COLOR: yellowish-brown; fire clouds on the rim and base

EXTERIOR SURFACE COLOR: yellowish-brown; fire clouds on the rim (pink fire clouding) and base

WALL THICKNESS (IN MM): rim, $6.5 \mathrm{~mm}$

INTERIOR SURFACE TREATMENT: smoothed on the rim

EXTERIOR SURFACE TREATMENT: burnished

HEIGHT (IN CM): 11.5

ORIFICE DIAMETER (IN CM): 15.7

DIAMETER AT BOTTOM OF RIM OR NECK (IN CM): 12.0

BASE DIAMETER (IN CM) AND SHAPE OF BASE: 8.9; circular and flat

ESTIMATED VOLUME (IN LITERS): 1.1

DECORATION (INCLUDING MOTIF AND ELEMENTS WHEN APPARENT): The rim is divided into six rectangular panels by sets of two vertical engraved lines with upper and lower diagonal hatched triangle elements (Figure 5). The vertical lines-brackets are directly underneath the rim peaks. One of the rectangular panels is open, while the other five have a central engraved circle filled with excised punctations.

PIGMENT USE AND LOCATION ON VESSEL: none

TYPE AND VARIETY (IF KNOWN): Poynor Engraved, var. Blackburn

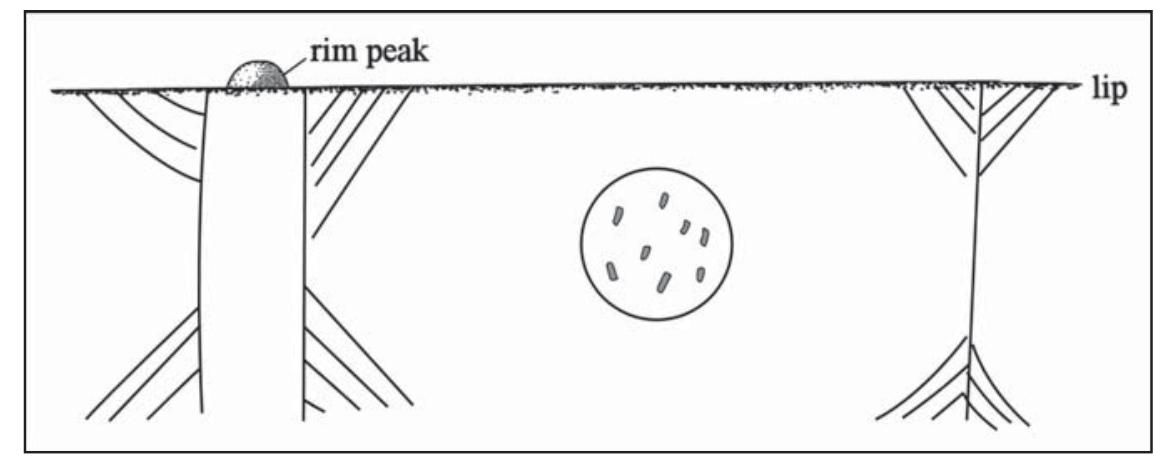

Figure 5. Decorative elements on Poynor Engraved, var. Blackburn carinated bowl (Vessel 4) from the Ballard Estates site (41AN53). 


\section{O. L. Ellis Site (41AN54)}

There are 15 ancestral Caddo ceramic vessels in the O. L. Ellis site collections at TARL. They include carinated bowls ( $\mathrm{n}=8,53.3$ percent), effigy bowls ( $\mathrm{n}=1,6.7$ percent), bottles $(\mathrm{n}=1,6.7$ percent), and jars ( $\mathrm{n}=5,33.3$ percent). These vessels were obtained by UT excavations in 1935 (from two burials) and from two burials dug by local residents in 1934; the vessels from that work were purchased by UT. A. T. Jackson noted in 1935 that there was a large Caddo habitation area about 90 m south of the cemetery.

SITE NAME OR SITE NUMBER: O. L. Ellis (41AN54)

VESSEL NO.: 1

VESSEL FORM: globular carinated bowl

NON-PLASTICS AND PASTE: grog

RIM AND LIP FORM: Direct rim and rounded lip

CORE COLOR: Unknown

INTERIOR SURFACE COLOR: red; fire clouds on the rim

EXTERIOR SURFACE COLOR: yellowish-brown; fire clouds on the rim, body, and base (including pink fire clouds on the rim and body); organic residue on the rim and body

WALL THICKNESS (IN MM): rim, $6.4 \mathrm{~mm}$

INTERIOR SURFACE TREATMENT: burnished on the rim; smoothed on the remainder

EXTERIOR SURFACE

TREATMENT: burnished

HEIGHT (IN CM): 12.4

ORIFICE DIAMETER (IN CM): 15.8

DIAMETER AT BOTTOM OF RIM OR NECK (IN CM): 15.8

BASE DIAMETER (IN CM) AND SHAPE OF BASE: 5.6; circular and flat

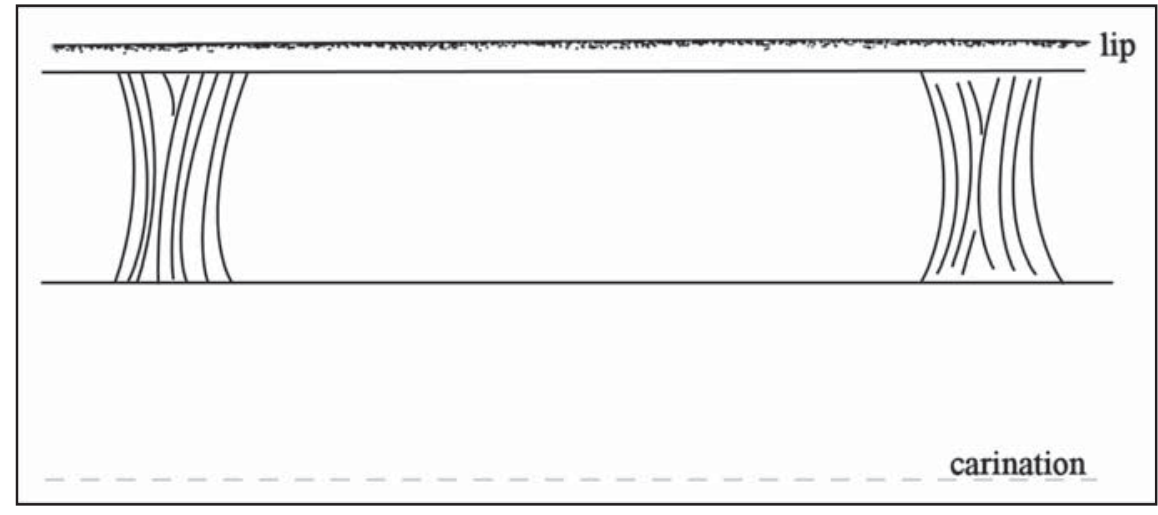

Figure 6. Decorative elements on Poynor Engraved, var. Hood carinated bowl (Vessel 1) from the O. L. Ellis site (41AN54).

ESTIMATED VOLUME (IN LITERS): 1.2

DECORATION (INCLUDING MOTIF AND ELEMENTS WHEN APPARENT): The rim is divided into four oval-shaped panels by vertical bracket elements filled with curvilinear engraved lines (Figure 6).

PIGMENT USE AND LOCATION ON VESSEL: none

TYPE AND VARIETY (IF KNOWN): Poynor Engraved, var. Hood 
SITE NAME OR SITE NUMBER: O. L. Ellis (41AN54)

VESSEL NO.: 2

VESSEL FORM: Carinated bowl

NON-PLASTICS AND PASTE: grog

RIM AND LIP FORM: Direct rim and rounded lip

CORE COLOR: F (fired in a reducing environment and cooled in the open air)

INTERIOR SURFACE COLOR: yellowish-brown; fire clouds on the base

EXTERIOR SURFACE COLOR: reddish-brown; fire clouds on the rim, body, and base

WALL THICKNESS (IN MM): rim, $6.5 \mathrm{~mm}$

INTERIOR SURFACE TREATMENT: smoothed

EXTERIOR SURFACE TREATMENT: burnished

HEIGHT (IN CM): 6.4

ORIFICE DIAMETER (IN CM): 13.5

DIAMETER AT BOTTOM OF RIM OR NECK (IN CM): 13.3

BASE DIAMETER (IN CM) AND SHAPE OF BASE: 5.3; circular and flat

ESTIMATED VOLUME (IN LITERS): 0.50

DECORATION (INCLUDING MOTIF AND ELEMENTS WHEN APPARENT): The rim of the vessel is divided into four panels by sets of curvilinear engraved lines. Within the panels are two sets of hooked arm elements and two sets of stacked hatched triangle elements (Figure 7). The vessel body has horizontal brushing marks.

PIGMENT USE AND LOCATION ON VESSEL: white kaolin clay pigment in the engraved lines

TYPE AND VARIETY (IF KNOWN): Poynor Engraved, var. $\mathrm{N}-\mathrm{O}$

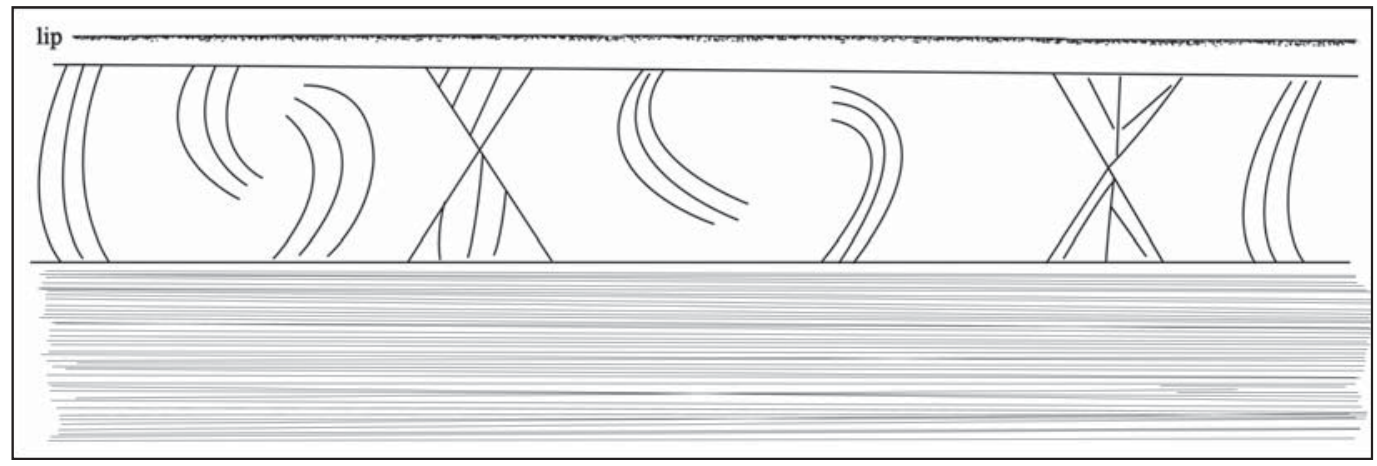

Figure 7. Decorative elements on Poynor Engraved, var. $\mathrm{N}$ - $\mathrm{O}$ carinated bowl (Vessel 2) from the O. L. Ellis site (41AN54). 
SITE NAME OR SITE NUMBER: O. L. Ellis (41AN54)

VESSEL NO.: 4

VESSEL FORM: Effigy bowl with tail rider

NON-PLASTICS AND PASTE: grog

RIM AND LIP FORM: Direct rim and rounded lip

CORE COLOR: $\mathrm{F}$ (fired in a reducing environment and cooled in the open air)

INTERIOR SURFACE COLOR: reddish-brown; fire clouds on the body and base

EXTERIOR SURFACE COLOR: reddish-brown; fire clouds on the rim, body, and base; organic residue on the body

WALL THICKNESS (IN MM): rim, $5.6 \mathrm{~mm}$

INTERIOR SURFACE TREATMENT: smoothed

EXTERIOR SURFACE TREATMENT: burnished

HEIGHT (IN CM): 8.9

ORIFICE DIAMETER (IN CM): 16.5

DIAMETER AT BOTTOM OF RIM OR NECK (IN CM): N/A

BASE DIAMETER (IN CM) AND SHAPE OF BASE: 9.1; circular and flat

ESTIMATED VOLUME (IN LITERS): 0.88

DECORATION (INCLUDING MOTIF AND ELEMENTS WHEN APPARENT): The rim has three widely-spaced horizontal engraved lines. The bird head effigy (68 $\mathrm{mm}$ in length, $54 \mathrm{~mm}$ in height, and $8.5 \mathrm{~mm}$ thick) has excised eyes that are $7 \mathrm{~mm}$ in diameter. The tail rider is a quadruped with a long tail, perhaps depicting a dog, and excised eyes. The tail rider is $73 \mathrm{~mm}$ in length, $37 \mathrm{~mm}$ in height, and 41 $\mathrm{mm}$ in width.

PIGMENT USE AND LOCATION ON VESSEL: white pigment in the engraved lines

TYPE AND VARIETY (IF KNOWN): Hood Engraved, var. Allen

SITE NAME OR SITE NUMBER: O. L. Ellis (41AN54)

VESSEL NO.: 5

VESSEL FORM: Carinated bowl

NON-PLASTICS AND PASTE: grog 
RIM AND LIP FORM: Direct rim and rounded lip

CORE COLOR: $\mathrm{F}$ (fired in a reducing environment and cooled in the open air)

INTERIOR SURFACE COLOR: yellowish-brown

EXTERIOR SURFACE COLOR: yellowish-brown; fire clouds on the rim and body

WALL THICKNESS (IN MM): rim, $5.0 \mathrm{~mm}$

INTERIOR SURFACE TREATMENT: smoothed

EXTERIOR SURFACE TREATMENT: burnished

HEIGHT (IN CM): 7.6

ORIFICE DIAMETER (IN CM): 12.5

DIAMETER AT BOTTOM OF RIM OR NECK (IN CM): 12.5

BASE DIAMETER (IN CM) AND SHAPE OF BASE: 5.7; circular and flat

ESTIMATED VOLUME (IN LITERS): 0.58

DECORATION (INCLUDING MOTIF AND ELEMENTS WHEN APPARENT): The rim is divided into an unknown number of rectangular panels by vertical brackets that end in upper and lower open triangle elements (Figure 8). The upper and lower horizontal lines of the panels have excised pendant triangles that either point downward towards the vessel carination or upwards towards the vessel rim.

PIGMENT USE AND LOCATION ON VESSEL: none

TYPE AND VARIETY (IF KNOWN): Poynor Engraved, var. Freeman

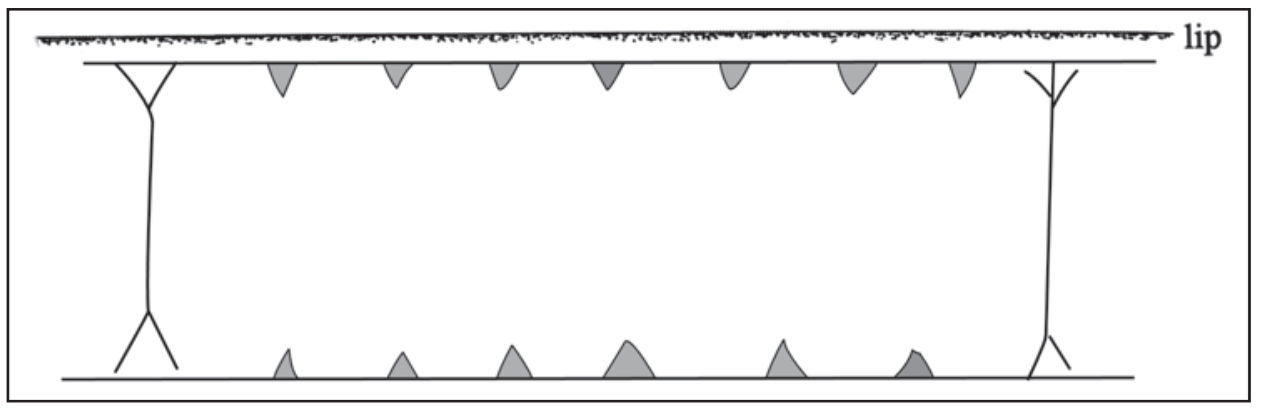

Figure 8. Decorative elements on Poynor Engraved, var. Freeman carinated bowl (Vessel 5) from the O. L. Ellis site (41AN54).

SITE NAME OR SITE NUMBER: O. L. Ellis (41AN54)

VESSEL NO.: 6

VESSEL FORM: Cylindrical bottle with a short neck 
NON-PLASTICS AND PASTE: bone and hematite

RIM AND LIP FORM: Direct rim and rounded lip

CORE COLOR: $\mathrm{F}$ (fired in a reducing environment and cooled in the open air)

INTERIOR SURFACE COLOR: dark yellowish-brown

EXTERIOR SURFACE COLOR: yellowish-brown; fire clouds on the neck and body; organic residue on the neck and body

WALL THICKNESS (IN MM): neck, $7.3 \mathrm{~mm}$

INTERIOR SURFACE TREATMENT: none

EXTERIOR SURFACE TREATMENT: burnished

HEIGHT (IN CM): 28.4

ORIFICE DIAMETER (IN CM): 3.7

DIAMETER AT BOTTOM OF RIM OR NECK (IN CM): 6.3

BASE DIAMETER (IN CM) AND SHAPE OF BASE: 8.2; circular and flat

ESTIMATED VOLUME (IN LITERS): 0.93

DECORATION (INCLUDING MOTIF AND ELEMENTS WHEN APPARENT): The vessel body is divided into four broad panels by sets of engraved vertical brackets filled with curvilinear engraved lines (Figure 9).

PIGMENT USE AND LOCATION ON VESSEL: red ochre-rich clay pigment in engraved lines

TYPE AND VARIETY (IF KNOWN): Poynor Engraved, var. unspecified

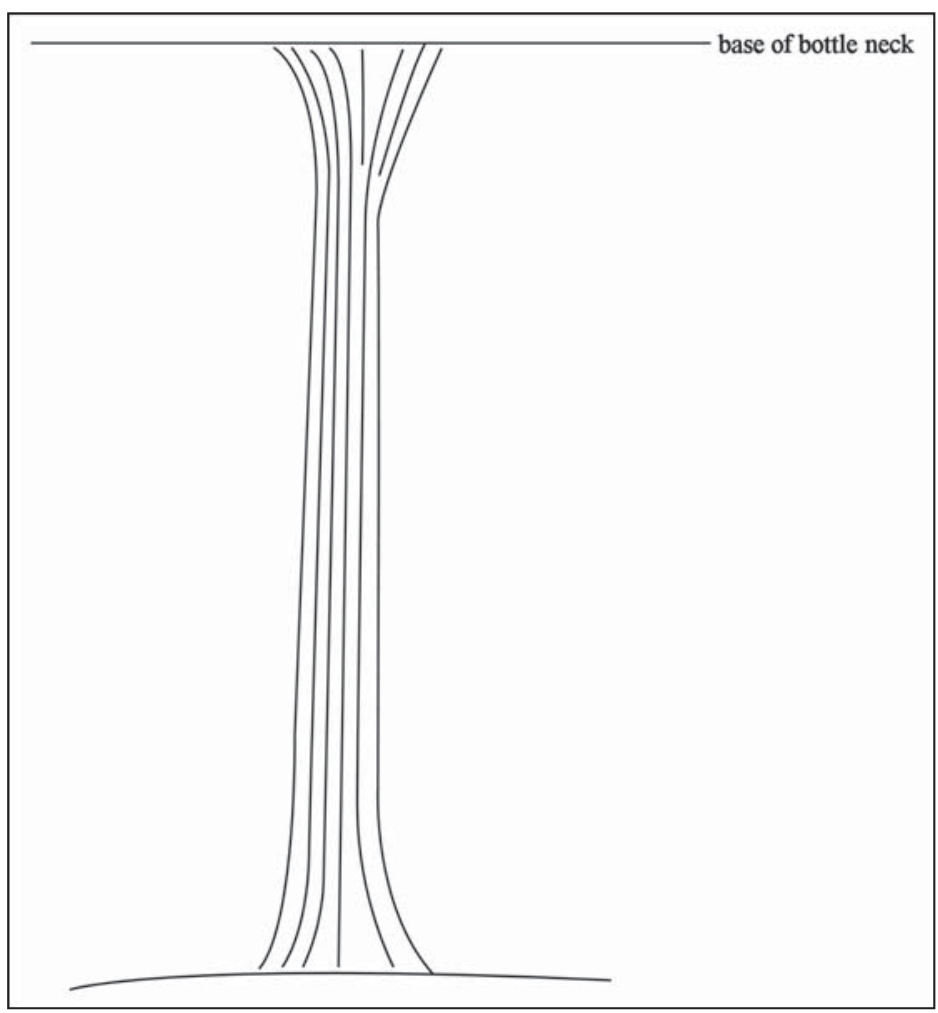

Figure 9. Decorative elements on Poynor Engraved, var. unspecified bottle (Vessel 6) from the O. L. Ellis site (41AN54). 
SITE NAME OR SITE NUMBER: O. L. Ellis (41AN54)

VESSEL NO.: 7

VESSEL FORM: Jar with two opposed lug handles (16.3 x $33.6 \mathrm{~mm}$ in width and length)

NON-PLASTICS AND PASTE: grog

RIM AND LIP FORM: Direct rim and rounded lip

CORE COLOR: Unknown

INTERIOR SURFACE COLOR: yellowish-brown; fire clouds on the rim, body, and base

EXTERIOR SURFACE COLOR: yellowish-brown; fire clouds on the rim and base

WALL THICKNESS (IN MM): rim, $6.2 \mathrm{~mm}$

INTERIOR SURFACE TREATMENT: smoothed

EXTERIOR SURFACE TREATMENT: none

HEIGHT (IN CM): 24.5

ORIFICE DIAMETER (IN CM): 13.0

DIAMETER AT BOTTOM OF RIM OR NECK (IN CM): N/A

BASE DIAMETER (IN CM) AND SHAPE OF BASE: 9.0; circular and flat

ESTIMATED VOLUME (IN LITERS): 2.8

DECORATION (INCLUDING MOTIF AND ELEMENTS WHEN APPARENT): The rim and vessel body have horizontal brushing marks

PIGMENT USE AND LOCATION ON VESSEL: none

TYPE AND VARIETY (IF KNOWN): Bullard Brushed

SITE NAME OR SITE NUMBER: O. L. Ellis (41AN54)

VESSEL NO.: 8

VESSEL FORM: Jar with two appliqued lug handles

NON-PLASTICS AND PASTE: grog

RIM AND LIP FORM: Everted rim and rounded lip

CORE COLOR: Unknown 
INTERIOR SURFACE COLOR: yellowish-brown; fire clouds on rim, body, and base

EXTERIOR SURFACE COLOR: yellowish-brown; fire clouds on the rim, body, and base

WALL THICKNESS (IN MM): rim, $4.3 \mathrm{~mm}$

INTERIOR SURFACE TREATMENT: smoothed on rim

EXTERIOR SURFACE TREATMENT: none

HEIGHT (IN CM): 13.5

ORIFICE DIAMETER (IN CM): 13.0

DIAMETER AT BOTTOM OF RIM OR NECK (IN CM): 10.8

BASE DIAMETER (IN CM) AND SHAPE OF BASE: 7.5; circular and flat

ESTIMATED VOLUME (IN LITERS): 1.1

DECORATION (INCLUDING MOTIF AND ELEMENTS WHEN APPARENT): The vessel rim has horizontal brushing marks. The vessel body has two opposed sets of concentric pinched circles (see Suhm and Jelks 1962:Plate 46j).

PIGMENT USE AND LOCATION ON VESSEL: none

TYPE AND VARIETY (IF KNOWN): Killough Pinched

SITE NAME OR SITE NUMBER: O. L. Ellis (41AN54)

VESSEL NO.: 9

VESSEL FORM: globular carinated bowl

NON-PLASTICS AND PASTE: grog

RIM AND LIP FORM: Direct rim and rounded lip

CORE COLOR: Unknown

INTERIOR SURFACE COLOR: yellowish-brown; fire clouds on the body and base

EXTERIOR SURFACE COLOR: yellowish-brown; fire clouds on the rim, body, and base; pink fire clouds on the body

WALL THICKNESS (IN MM): rim, $5.7 \mathrm{~mm}$

INTERIOR SURFACE TREATMENT: smoothed

EXTERIOR SURFACE TREATMENT: burnished 
HEIGHT (IN CM): 12.7

ORIFICE DIAMETER (IN CM): 16.5

DIAMETER AT BOTTOM OF RIM OR NECK (IN CM): 12.6

BASE DIAMETER (IN CM) AND SHAPE OF BASE: 8.9; circular and flat

ESTIMATED VOLUME (IN LITERS): 1.3

DECORATION (INCLUDING MOTIF AND ELEMENTS WHEN APPARENT): The rim is divided into seven oval-shaped panels by sets of vertical engraved brackets as well as upper and lower horizontal engraved lines (Figure 10).

PIGMENT USE AND LOCATION ON VESSEL: none

TYPE AND VARIETY (IF KNOWN): Poynor Engraved, var. Hood

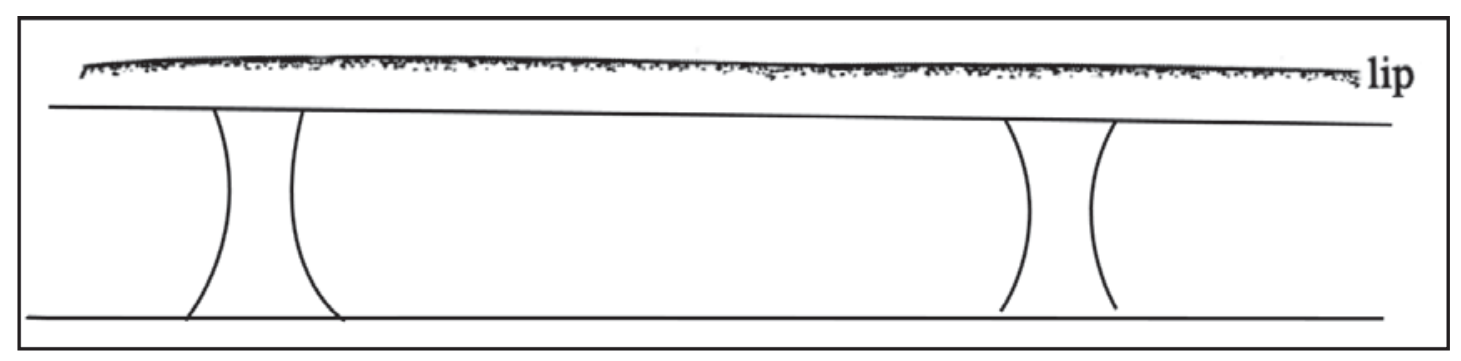

Figure 10. Decorative elements on a Poynor Engraved, var. Hood carinated bowl (Vessel 9) from the O. L. Ellis site (41AN54).

SITE NAME OR SITE NUMBER: O. L. Ellis (41AN54)

VESSEL NO.: 10

VESSEL FORM: globular carinated bowl

NON-PLASTICS AND PASTE: grog

RIM AND LIP FORM: Direct rim and rounded lip

CORE COLOR: Unknown

INTERIOR SURFACE COLOR: yellowish-brown; fire clouds on the rim

EXTERIOR SURFACE COLOR: yellowish-brown; fire clouds on the rim, body, and base

WALL THICKNESS (IN MM): rim, $5.9 \mathrm{~mm}$

INTERIOR SURFACE TREATMENT: smoothed

EXTERIOR SURFACE TREATMENT: burnished 
HEIGHT (IN CM): 15.2

ORIFICE DIAMETER (IN CM): 20.3

DIAMETER AT BOTTOM OF RIM OR NECK (IN CM): 20.7

BASE DIAMETER (IN CM) AND SHAPE OF BASE: 7.6; circular and flat

ESTIMATED VOLUME (IN LITERS): 2.8

DECORATION (INCLUDING MOTIF AND ELEMENTS WHEN APPARENT): The rim panel is divided into seven oval-shaped panels by sets of vertical brackets (Figure 11) and upper and lower horizontal engraved lines. The brackets are filled with cross-hatched engraved lines.

PIGMENT USE AND LOCATION ON VESSEL: none

TYPE AND VARIETY (IF KNOWN): Poynor Engraved, var. Hood

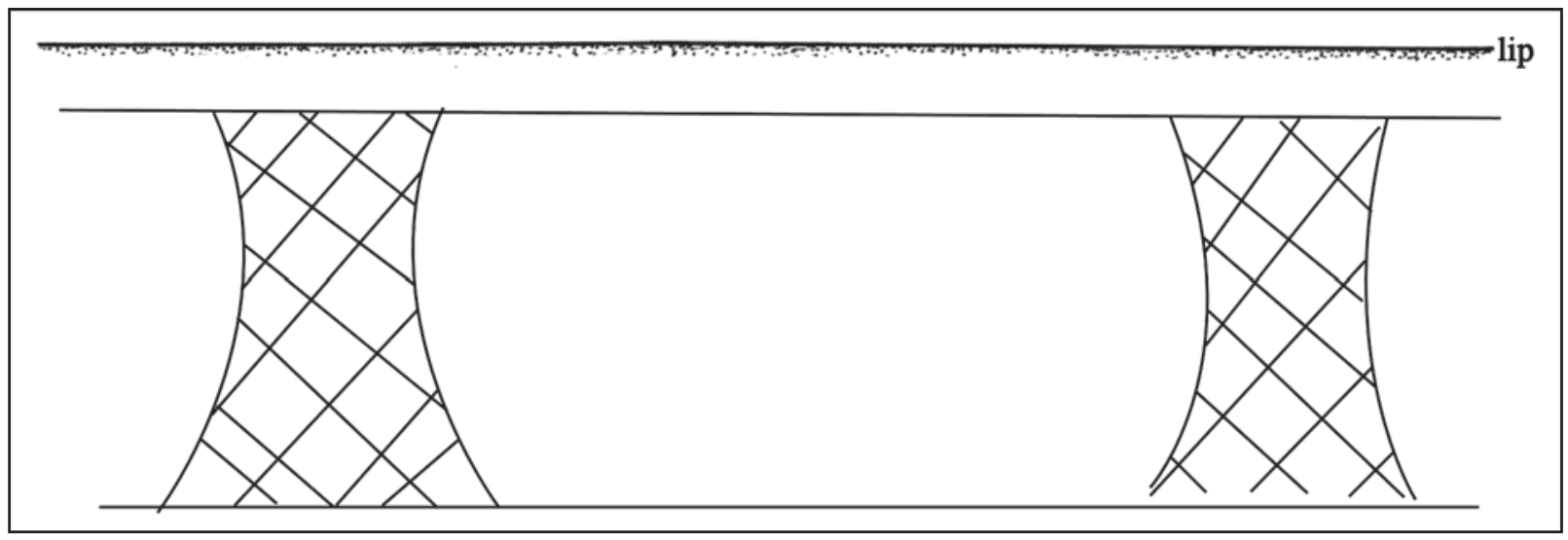

Figure 11. Decorative elements on a Poynor Engraved, var. Hood carinated bowl (Vessel 10) from the O. L. Ellis site (41AN54).

SITE NAME OR SITE NUMBER: O. L. Ellis (41AN54)

VESSEL NO.: 11

VESSEL FORM: globular carinated bowl with two opposed appliqued lugs (19 x $8 \mathrm{~mm}$ in length and width). The lugs have very small (1.3 $\mathrm{mm}$ in diameter) suspension holes.

NON-PLASTICS AND PASTE: grog

RIM AND LIP FORM: Everted rim and rounded lip

CORE COLOR: Unknown

INTERIOR SURFACE COLOR: yellowish-brown; fire clouds on the rim, body, and base

EXTERIOR SURFACE COLOR: yellowish-brown; fire clouds on the body and base 
WALL THICKNESS (IN MM): rim, $4.4 \mathrm{~mm}$

INTERIOR SURFACE TREATMENT: smoothed

EXTERIOR SURFACE TREATMENT: burnished

HEIGHT (IN CM): 6.6

ORIFICE DIAMETER (IN CM): 8.6

DIAMETER AT BOTTOM OF RIM OR NECK (IN CM): 8.3

BASE DIAMETER (IN CM) AND SHAPE OF BASE: 5.7; circular and flat

ESTIMATED VOLUME (IN LITERS): 0.34

DECORATION (INCLUDING MOTIF AND ELEMENTS WHEN APPARENT): The rim is divided into four oval-shaped panels by upper and lower horizontal engraved lines and four excised vertical bracket elements (Figure 12).

PIGMENT USE AND LOCATION ON VESSEL: white kaolin clay pigment in the engraved lines

TYPE AND VARIETY (IF KNOWN): Poynor Engraved, var. Hood

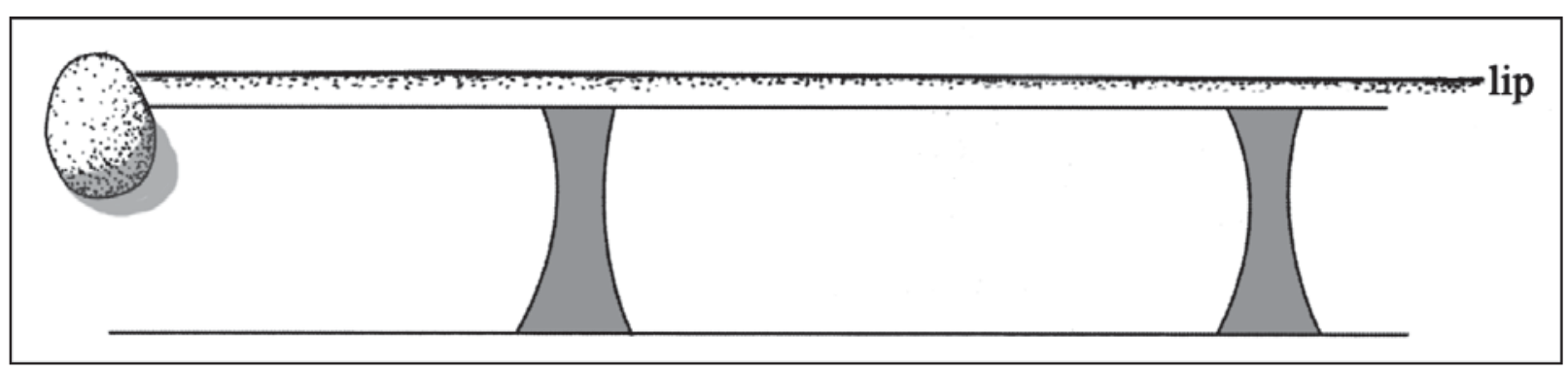

Figure 12. Decorative elements on a Poynor Engraved, var. Hood carinated bowl (Vessel 11) from the O. L. Ellis site (41AN54).

SITE NAME OR SITE NUMBER: O. L. Ellis (41AN54)

VESSEL NO.: 12

VESSEL FORM: Jar

NON-PLASTICS AND PASTE: grog

RIM AND LIP FORM: Everted rim and rounded lip

CORE COLOR: Unknown

INTERIOR SURFACE COLOR: reddish-brown; sooted on rim, body, and base

EXTERIOR SURFACE COLOR: dark reddish-brown; fire clouds on the base 
WALL THICKNESS (IN MM): rim, $5.0 \mathrm{~mm}$

INTERIOR SURFACE TREATMENT: smoothed

EXTERIOR SURFACE TREATMENT: smoothed only on the body

HEIGHT (IN CM): 15.8

ORIFICE DIAMETER (IN CM): 14.5

DIAMETER AT BOTTOM OF RIM OR NECK (IN CM): 11.4

BASE DIAMETER (IN CM) AND SHAPE OF BASE: 9.3; circular and flat

ESTIMATED VOLUME (IN LITERS): 1.4

DECORATION (INCLUDING MOTIF AND ELEMENTS WHEN APPARENT): The vessel rim has six alternating sets of incised triangles (each defined by three diagonal incised lines pitched in opposite directions) filled with rows of tool punctations (Figure 13). There is a single horizontal incised line at the rim-body juncture.

PIGMENT USE AND LOCATION ON VESSEL: none

TYPE AND VARIETY (IF KNOWN): Maydelle Incised

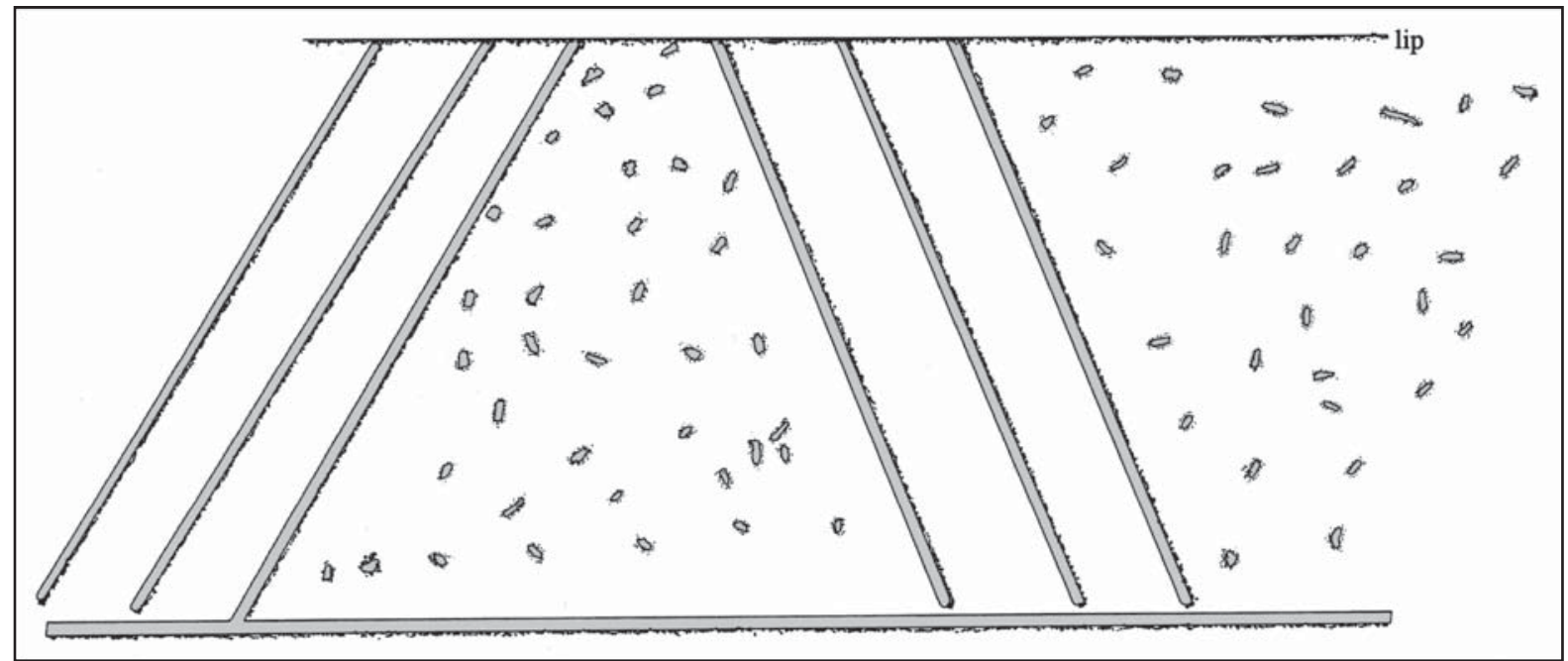

Figure 13. Decorative elements on a Maydelle Incised jar (Vessel 12) from the O. L. Ellis site (41AN54).

SITE NAME OR SITE NUMBER: O. L. Ellis (41AN54)

VESSEL NO.: 13

VESSEL FORM: Miniature jar with two strap handles $(21.4 \mathrm{~mm}$ in length, $6.9 \mathrm{~mm}$ in width, and $4.7 \mathrm{~mm}$ thick)

NON-PLASTICS AND PASTE: grog 
RIM AND LIP FORM: Everted rim and rounded lip

CORE COLOR: Unknown

INTERIOR SURFACE COLOR: yellowish-brown; fire clouds on the rim, body, and base

EXTERIOR SURFACE COLOR: yellowish-brown; fire clouds on the rim, body, and base

WALL THICKNESS (IN MM): rim, $5.4 \mathrm{~mm}$

INTERIOR SURFACE TREATMENT: smoothed

EXTERIOR SURFACE TREATMENT: none

HEIGHT (IN CM): 7.5

ORIFICE DIAMETER (IN CM): 6.7

DIAMETER AT BOTTOM OF RIM OR NECK (IN CM): 5.7

BASE DIAMETER (IN CM) AND SHAPE OF BASE: 3.5; circular and flat

ESTIMATED VOLUME (IN LITERS): 0.3

DECORATION (INCLUDING MOTIF AND ELEMENTS WHEN APPARENT): Vertical brushing marks on the vessel body; the rim is plain.

PIGMENT USE AND LOCATION ON VESSEL: none

TYPE AND VARIETY (IF KNOWN): Bullard Brushed

SITE NAME OR SITE NUMBER: O. L. Ellis (41AN54)

VESSEL NO.: 14

VESSEL FORM: globular carinated bowl

NON-PLASTICS AND PASTE: grog

RIM AND LIP FORM: Everted rim and rounded lip

CORE COLOR: F (fired in a reducing environment and cooled in the open air)

INTERIOR SURFACE COLOR: red; fire clouds on the rim and base

EXTERIOR SURFACE COLOR: yellowish-brown; fire clouds on the rim and body (pink fire clouds)

WALL THICKNESS (IN MM): rim, $4.6 \mathrm{~mm}$

INTERIOR SURFACE TREATMENT: smoothed on the rim 
EXTERIOR SURFACE TREATMENT: burnished

HEIGHT (IN CM): 11.4

ORIFICE DIAMETER (IN CM): 13.5

DIAMETER AT BOTTOM OF RIM OR NECK (IN CM): 12.0

BASE DIAMETER (IN CM) AND SHAPE OF BASE: 6.5; circular and flat

ESTIMATED VOLUME (IN LITERS): 0.92

DECORATION (INCLUDING MOTIF AND ELEMENTS WHEN APPARENT): The rim has two horizontal engraved lines with open pendant triangle elements (Figure 14).

PIGMENT USE AND LOCATION ON VESSEL: none

TYPE AND VARIETY (IF KNOWN): Patton Engraved, var. Allen

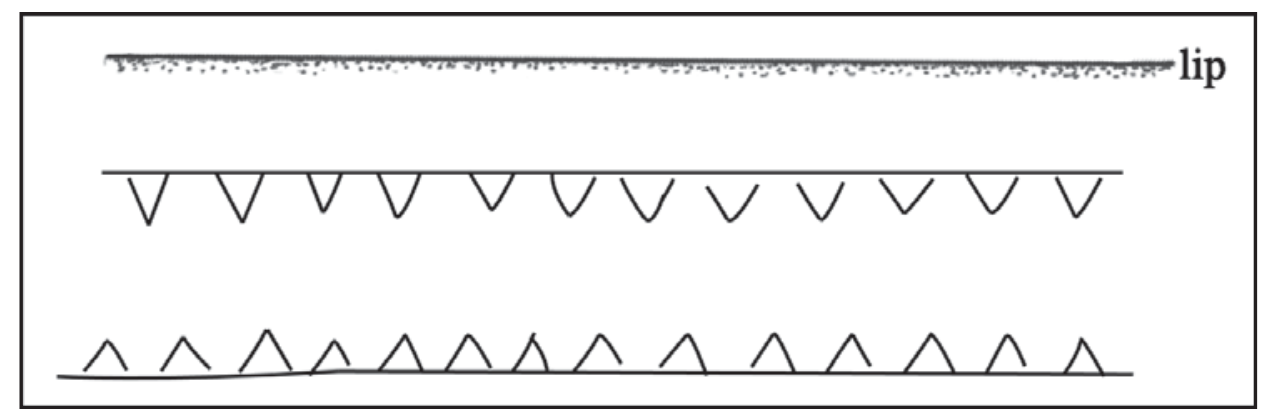

Figure 14. Decorative elements on a Patton Engraved, var. Allen carinated bowl (Vessel 14) from the O. L. Ellis site (41AN54).

SITE NAME OR SITE NUMBER: O. L. Ellis (41AN54)

VESSEL NO.: 15

VESSEL FORM: Jar with opposed appliqued lugs (17.6 mm in height and $19.6 \mathrm{~mm}$ in width)

NON-PLASTICS AND PASTE: grog

RIM AND LIP FORM: Direct rim and rounded lip

CORE COLOR: Unknown

INTERIOR SURFACE COLOR: yellowish-brown; fire clouds on the rim and body

EXTERIOR SURFACE COLOR: yellowish-brown; fire clouds on the base

WALL THICKNESS (IN MM): rim, $5.6 \mathrm{~mm}$

INTERIOR SURFACE TREATMENT: smoothed 
EXTERIOR SURFACE TREATMENT: none

HEIGHT (IN CM): 10.5

ORIFICE DIAMETER (IN CM): 10.7

DIAMETER AT BOTTOM OF RIM OR NECK (IN CM): 10.7

BASE DIAMETER (IN CM) AND SHAPE OF BASE: 7.5; circular and flat

ESTIMATED VOLUME (IN LITERS): 0.67

DECORATION (INCLUDING MOTIF AND ELEMENTS WHEN APPARENT): The rim has two horizontal rows of large tool punctations. There are also tool punctations under the two opposed lugs.

PIGMENT USE AND LOCATION ON VESSEL: none

TYPE AND VARIETY (IF KNOWN): Unidentified utility ware

SITE NAME OR SITE NUMBER: O. L. Ellis (41AN54)

VESSEL NO.: 16

VESSEL FORM: globular carinated bowl

NON-PLASTICS AND PASTE: grog

RIM AND LIP FORM: Direct rim and rounded lip

CORE COLOR: C (incompletely oxidized during firing)

INTERIOR SURFACE COLOR: yellowish-brown; fire clouds on the body

EXTERIOR SURFACE COLOR: yellowish-brown; pink fire clouds on the body

WALL THICKNESS (IN MM): rim, $7.2 \mathrm{~mm}$; body, $9.1 \mathrm{~mm}$

INTERIOR SURFACE TREATMENT: smoothed

EXTERIOR SURFACE TREATMENT: smoothed

HEIGHT (IN CM): 10.4

ORIFICE DIAMETER (IN CM): 17.1

DIAMETER AT BOTTOM OF RIM OR NECK (IN CM): 16.9

BASE DIAMETER (IN CM) AND SHAPE OF BASE: N/A

ESTIMATED VOLUME (IN LITERS): 1.1 
DECORATION (INCLUDING MOTIF AND ELEMENTS WHEN APPARENT): There is one excised vertical bracket visible on the rim section of the vessel fragment.

PIGMENT USE AND LOCATION ON VESSEL: none

TYPE AND VARIETY (IF KNOWN): Poynor Engraved, var. Hood

\section{Lee Ellis Site (41AN56)}

There is only a single ancestral Caddo ceramic vessel from the Lee Ellis site in the TARL collections. It is a fragment of a Bullard Brushed jar donated to UT by the landowner.

SITE NAME OR SITE NUMBER: Lee Ellis (41AN56)

VESSEL NO.: 98

VESSEL FORM: Jar

NON-PLASTICS AND PASTE: grog and bone

RIM AND LIP FORM: N/A

CORE COLOR: F (fired in a reducing environment and cooled in the open air)

INTERIOR SURFACE COLOR: yellowish-brown

EXTERIOR SURFACE COLOR: yellowish-brown; fire clouds on the body and base

WALL THICKNESS (IN MM): body, $8.4 \mathrm{~mm}$

INTERIOR SURFACE TREATMENT: none

EXTERIOR SURFACE TREATMENT: none

HEIGHT (IN CM): 5.4+

ORIFICE DIAMETER (IN CM): 7.6

DIAMETER AT BOTTOM OF RIM OR NECK (IN CM): N/A

BASE DIAMETER (IN CM) AND SHAPE OF BASE: 5.1; circular and flat

ESTIMATED VOLUME (IN LITERS): 0.25+

DECORATION (INCLUDING MOTIF AND ELEMENTS WHEN APPARENT): Vertical brushing marks on the vessel body

PIGMENT USE AND LOCATION ON VESSEL: none

TYPE AND VARIETY (IF KNOWN): Bullard Brushed 


\section{Dabbs Estate Site (41AN57)}

The TARL collections have three Caddo ceramic vessels from the Dabbs Estate site. Two of the vessels are plain wares, and the third is a Poynor Engraved bottle. These vessels were part of the Bates Windham collection donated to UT in 1935. UT excavations at the site were conducted after the vessels from a burial had been exposed in an eroded ravine, but no more vessels or burial features were identified in that work.

SITE NAME OR SITE NUMBER: Dabbs Estate (41AN57)

VESSEL NO.: 1

VESSEL FORM: Carinated bowl

NON-PLASTICS AND PASTE: grog and bone

RIM AND LIP FORM: Direct rim and rounded lip

CORE COLOR: F (fired in a reducing environment and cooled in the open air)

INTERIOR SURFACE COLOR: reddish-brown

EXTERIOR SURFACE COLOR: reddish-brown; fire clouds on the base

WALL THICKNESS (IN MM): rim, $5.2 \mathrm{~mm}$

INTERIOR SURFACE TREATMENT: smoothed

EXTERIOR SURFACE TREATMENT: smoothed

HEIGHT (IN CM): 7.5

ORIFICE DIAMETER (IN CM): 14.0

DIAMETER AT BOTTOM OF RIM OR NECK (IN CM): 13.8

BASE DIAMETER (IN CM) AND SHAPE OF BASE: 7.2; circular and flat

ESTIMATED VOLUME (IN LITERS): 0.63

DECORATION (INCLUDING MOTIF AND ELEMENTS WHEN APPARENT): Plain

PIGMENT USE AND LOCATION ON VESSEL: none

TYPE AND VARIETY (IF KNOWN): Unidentified plain ware

SITE NAME OR SITE NUMBER: Dabbs Estate (41AN57)

VESSEL NO.: 3

VESSEL FORM: Miniature bowl with opposed tab tails 
NON-PLASTICS AND PASTE: grog

RIM AND LIP FORM: Direct rim and rounded lip

CORE COLOR: $\mathrm{G}$ (fired in a reducing environment and cooled in the open air)

INTERIOR SURFACE COLOR: grayish-brown

EXTERIOR SURFACE COLOR: yellowish-brown

WALL THICKNESS (IN MM): rim, $5.1 \mathrm{~mm}$

INTERIOR SURFACE TREATMENT: none

EXTERIOR SURFACE TREATMENT: none

HEIGHT (IN CM): 1.7

ORIFICE DIAMETER (IN CM): 3.1

DIAMETER AT BOTTOM OF RIM OR NECK (IN CM): N/A

BASE DIAMETER (IN CM) AND SHAPE OF BASE: 2.6; circular and flat

ESTIMATED VOLUME (IN LITERS): 0.2

DECORATION (INCLUDING MOTIF AND ELEMENTS WHEN APPARENT): Plain

PIGMENT USE AND LOCATION ON VESSEL: none

TYPE AND VARIETY (IF KNOWN): Undetermined plain ware

SITE NAME OR SITE NUMBER: Dabbs Estate (41AN57)

VESSEL NO.: 4

VESSEL FORM: Carinated bottle

NON-PLASTICS AND PASTE: grog

RIM AND LIP FORM: N/A

CORE COLOR: $\mathrm{G}$ (fired in a reducing environment and cooled in the open air)

INTERIOR SURFACE COLOR: dark grayish-brown

EXTERIOR SURFACE COLOR: yellowish-brown; fire clouds on the base

WALL THICKNESS (IN MM): neck, 8.6 mm

INTERIOR SURFACE TREATMENT: none 
EXTERIOR SURFACE TREATMENT: none

HEIGHT (IN CM): 12.7+

ORIFICE DIAMETER (IN CM): N/A

DIAMETER AT BOTTOM OF RIM OR NECK (IN CM): 5.1

BASE DIAMETER (IN CM) AND SHAPE OF BASE: 8.9; circular and flat

\section{ESTIMATED VOLUME (IN LITERS): 0.45+}

DECORATION (INCLUDING MOTIF AND ELEMENTS WHEN APPARENT): The vessel body is divided into two rectangular panels by vertical engraved columns filled with hatched lines (Figure 15). The panels have a hooked arm element (Var. P of Poynor Engraved), along with a large hatched pendant triangle. Each of the four corners of the panels have hatched triangular corner elements (Figure 15).

PIGMENT USE AND LOCATION ON VESSEL: none

TYPE AND VARIETY (IF KNOWN): Poynor Engraved, var. unspecified

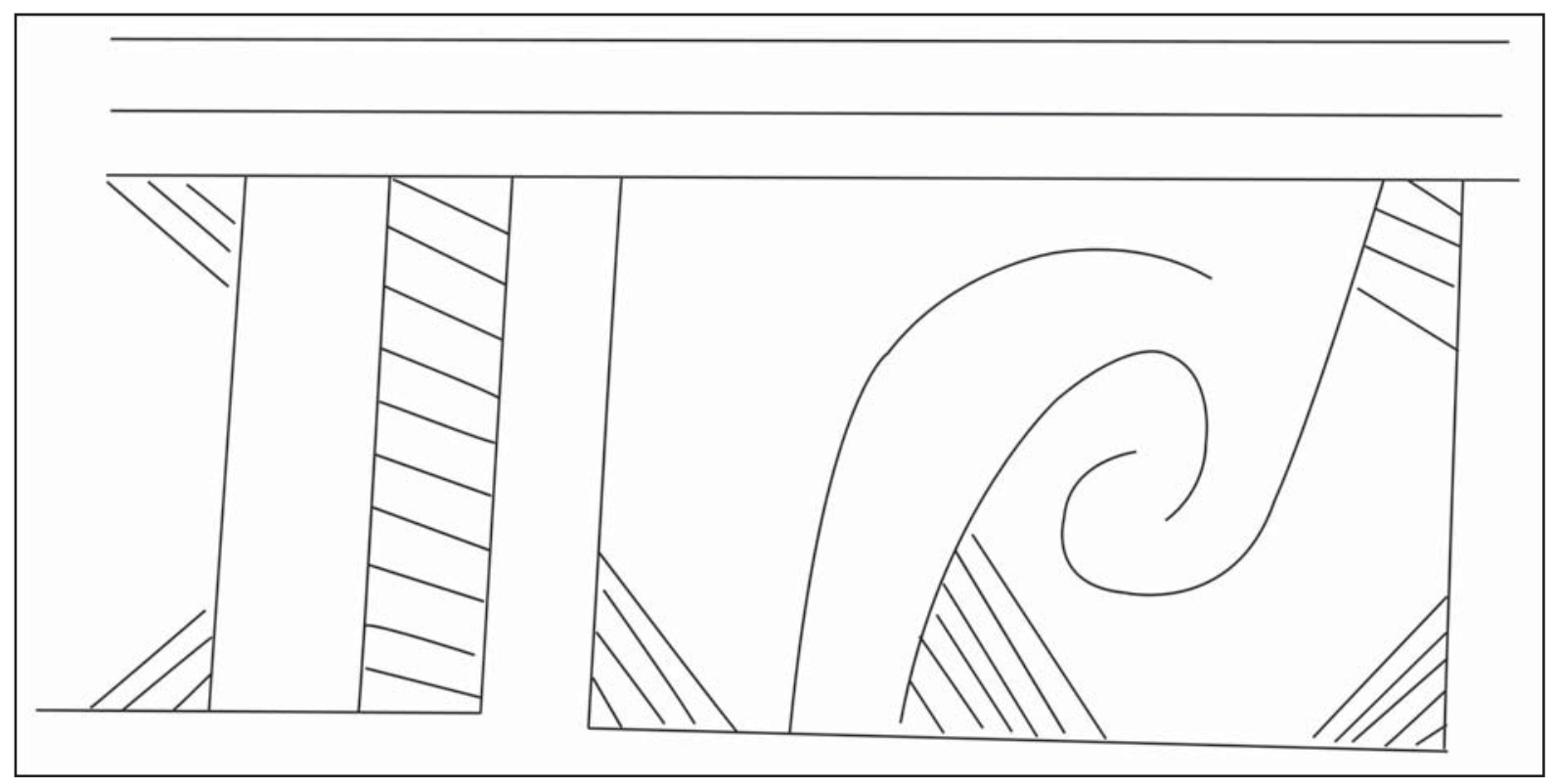

Figure 15. Decorative elements on a Poynor Engraved, var. unspecified bottle (Vessel 4) from the Dabbs Estate site (41AN57).

\section{H. Reagor Site (41CE15)}

There are three Caddo ceramic vessels from two different burials excavated by UT in 1935 at the A. H. Reagor site in the TARL collections. The vessels include a Bullard Brushed bowl and two fine ware carinated bowls of the Poynor Engraved and Patton Engraved types.

SITE NAME OR SITE NUMBER: A. H. Reagor (41CE15)

VESSEL NO:: 1, Burial AJ-1 
VESSEL FORM: Bowl

NON-PLASTICS AND PASTE: grog

RIM AND LIP FORM: Direct rim and rounded lip

CORE COLOR: $\mathrm{F}$ (fired in a reducing environment and cooled in the open air)

INTERIOR SURFACE COLOR: yellowish-brown

EXTERIOR SURFACE COLOR: yellowish-brown

WALL THICKNESS (IN MM): rim, $6.5 \mathrm{~mm}$

INTERIOR SURFACE TREATMENT: smoothed

EXTERIOR SURFACE TREATMENT: none

HEIGHT (IN CM): 7.0

ORIFICE DIAMETER (IN CM): 9.5

DIAMETER AT BOTTOM OF RIM OR NECK (IN CM): N/A

BASE DIAMETER (IN CM) AND SHAPE OF BASE: 5.1; circular and flat

ESTIMATED VOLUME (IN LITERS): 0.27

DECORATION (INCLUDING MOTIF AND ELEMENTS WHEN APPARENT): The rim and body of the vessel has vertical brushing marks.

PIGMENT USE AND LOCATION ON VESSEL: none

TYPE AND VARIETY (IF KNOWN): Bullard Brushed

SITE NAME OR SITE NUMBER: A. H. Reagor (41CE15)

VESSEL NO.: 2, Burial AJ-2

VESSEL FORM: globular carinated bowl

NON-PLASTICS AND PASTE: grog

RIM AND LIP FORM: Direct rim and rounded lip

CORE COLOR: F (fired in a reducing environment and cooled in the open air)

INTERIOR SURFACE COLOR: dark yellowish-brown; fire clouds on the base

EXTERIOR SURFACE COLOR: dark yellowish-brown; fire clouds on the rim, body, and base 
WALL THICKNESS (IN MM): rim, $5.6 \mathrm{~mm}$

INTERIOR SURFACE TREATMENT: burnished

EXTERIOR SURFACE TREATMENT: burnished

HEIGHT (IN CM): 8.9

ORIFICE DIAMETER (IN CM): 9.5

DIAMETER AT BOTTOM OF RIM OR NECK (IN CM): 9.5

BASE DIAMETER (IN CM) AND SHAPE OF BASE: 6.4; circular and flat

ESTIMATED VOLUME (IN LITERS): 0.50

DECORATION (INCLUDING MOTIF AND ELEMENTS WHEN APPARENT): The rim has four horizontal engraved lines with excised triangular tick marks.

PIGMENT USE AND LOCATION ON VESSEL: none

TYPE AND VARIETY (IF KNOWN): Patton Engraved, var. Allen

SITE NAME OR SITE NUMBER: A. H. Reagor (41CE15)

VESSEL NO:: 3, Burial AJ-2

VESSEL FORM: Carinated bowl

NON-PLASTICS AND PASTE: grog

RIM AND LIP FORM: Inverted rim and rounded lip

CORE COLOR: F (fired in a reducing environment and cooled in the open air)

INTERIOR SURFACE COLOR: reddish-brown; fire clouds on the base

EXTERIOR SURFACE COLOR: yellowish-brown; fire clouds on the body and base

WALL THICKNESS (IN MM): rim, $7.0 \mathrm{~mm}$

INTERIOR SURFACE TREATMENT: smoothed

EXTERIOR SURFACE TREATMENT: burnished

HEIGHT (IN CM): 12.5

ORIFICE DIAMETER (IN CM): 20.7

DIAMETER AT BOTTOM OF RIM OR NECK (IN CM): 21.1 
BASE DIAMETER (IN CM) AND SHAPE OF BASE: 8.3; circular and flat

\section{ESTIMATED VOLUME (IN LITERS): 1.5}

DECORATION (INCLUDING MOTIF AND ELEMENTS WHEN APPARENT): The rim is divided into four rectangular panels by four vertical engraved lines that end with upper and lower hatched triangular elements (Figure 16). There are also single horizontal engraved lines at the top and bottom of the panels. The vessel body has horizontal brushing marks.

PIGMENT USE AND LOCATION ON VESSEL: none

TYPE AND VARIETY (IF KNOWN): Poynor Engraved, var. Blackburn

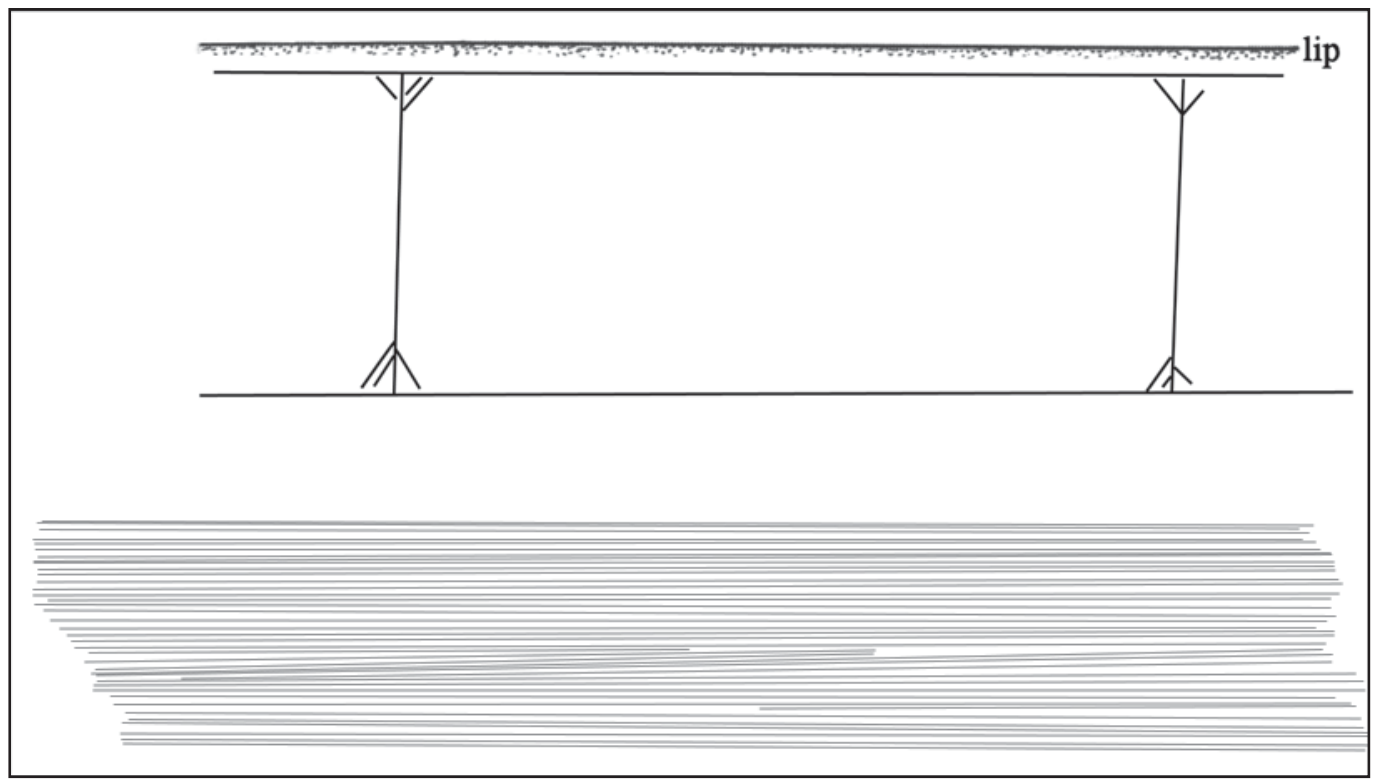

Figure 16. Decorative elements on a Poynor Engraved, var. Blackburn carinated bowl (Vessel 3) from the A. H. Reagor site (41CE15).

\section{John Bragg Site (41CE23)}

The TARL collection of ceramic vessels from the John Braggs site are from a single ancestral Caddo burial feature. They include eight vessels, among them fine ware carinated bowls $(n=2)$ and utility ware jars $(n=6)$. These vessels had been exposed from a disturbed burial by erosion in the early 1930s, and were purchased in 1933 by UT from a local resident. UT archaeologists conducted excavations at the site, but identified no other burial features there.

SITE NAME OR SITE NUMBER: John Braggs (41CE23)

VESSEL NO.: 1, Disturbed burial

VESSEL FORM: globular carinated bowl

NON-PLASTICS AND PASTE: bone and hematite

RIM AND LIP FORM: Direct rim and rounded lip 
CORE COLOR: $\mathrm{F}$ (fired in a reducing environment and cooled in the open air)

INTERIOR SURFACE COLOR: reddish-brown; fire clouds on the body and base

EXTERIOR SURFACE COLOR: reddish-brown; fire clouds on the rim, body, and base; pinkware

WALL THICKNESS (IN MM): rim, $6.6 \mathrm{~mm}$

INTERIOR SURFACE TREATMENT: none

EXTERIOR SURFACE TREATMENT: none

HEIGHT (IN CM): 15.8

ORIFICE DIAMETER (IN CM): 17.8

DIAMETER AT BOTTOM OF RIM OR NECK (IN CM): 17.7

BASE DIAMETER (IN CM) AND SHAPE OF BASE: 8.7; circular and flat

ESTIMATED VOLUME (IN LITERS): 2.5

DECORATION (INCLUDING MOTIF AND ELEMENTS WHEN APPARENT): The rim is divided into 10 oval-shaped panels by sets of vertical bracket elements filled with cross-hatched engraved lines (Figure 17). The top and bottom of the rim panel is defined by single horizontal engraved lines.

PIGMENT USE AND LOCATION ON VESSEL: none

TYPE AND VARIETY (IF KNOWN): Poynor Engraved, var. Hood

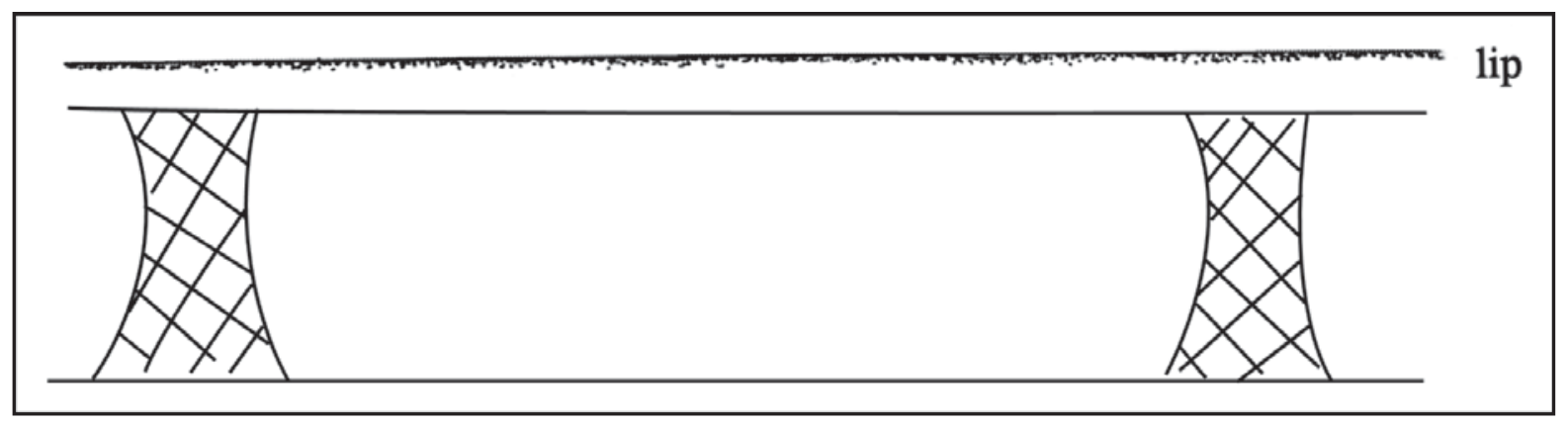

Figure 17. Decorative elements on a Poynor Engraved, var. Hood carinated bowl (Vessel 1) from the John Braggs site (41CE23).

SITE NAME OR SITE NUMBER: John Braggs (41CE23)

VESSEL NO.: 2, Disturbed burial

VESSEL FORM: Jar

NON-PLASTICS AND PASTE: grog and bone 
RIM AND LIP FORM: Direct rim and rounded lip

CORE COLOR: Unknown

INTERIOR SURFACE COLOR: yellowish-brown

EXTERIOR SURFACE COLOR: yellowish-brown

WALL THICKNESS (IN MM): rim, $6.3 \mathrm{~mm}$

INTERIOR SURFACE TREATMENT: smoothed

EXTERIOR SURFACE TREATMENT: none

HEIGHT (IN CM): 13.6

ORIFICE DIAMETER (IN CM): 11.8

DIAMETER AT BOTTOM OF RIM OR NECK (IN CM): 11.8

BASE DIAMETER (IN CM) AND SHAPE OF BASE: 8.2; circular and flat

ESTIMATED VOLUME (IN LITERS): 0.96

DECORATION (INCLUDING MOTIF AND ELEMENTS WHEN APPARENT): The vessel rim has a continuous series of diagonal incised lines pitched from right to left (Figure 18). Across the diagonal lines are drawn six incised triangle elements.

PIGMENT USE AND LOCATION ON VESSEL: none

TYPE AND VARIETY (IF KNOWN): Maydelle Incised

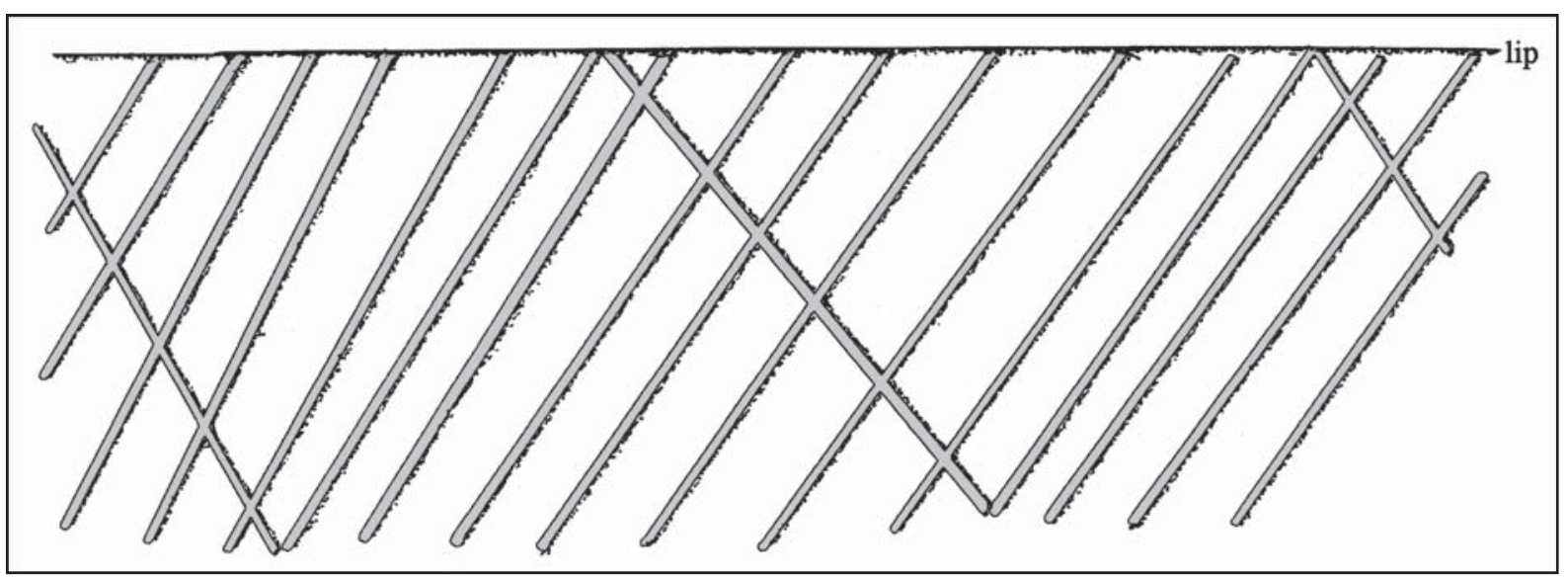

Figure 18. Decorative elements on a Maydelle Incised jar (Vessel 2) from the John Braggs site (41CE23). 
SITE NAME OR SITE NUMBER: John Braggs (41CE23)

VESSEL NO.: 3, Disturbed burial

VESSEL FORM: Jar

NON-PLASTICS AND PASTE: grog

RIM AND LIP FORM: Direct rim and flattened, ground-down lip

CORE COLOR: $\mathrm{G}$ (fired in a reducing environment and cooled in the open air)

INTERIOR SURFACE COLOR: yellowish-brown; fire clouds on rim, body, and base

EXTERIOR SURFACE COLOR: yellowish-brown; pink fire clouds on the body and base

WALL THICKNESS (IN MM): rim, $3.5 \mathrm{~mm}$

INTERIOR SURFACE TREATMENT: smoothed

EXTERIOR SURFACE TREATMENT: none

HEIGHT (IN CM): 13.8

ORIFICE DIAMETER (IN CM): 13.5

DIAMETER AT BOTTOM OF RIM OR NECK (IN CM): N/A

BASE DIAMETER (IN CM) AND SHAPE OF BASE: 11.0; circular and flat

ESTIMATED VOLUME (IN LITERS): 1.1

DECORATION (INCLUDING MOTIF AND ELEMENTS WHEN APPARENT): The vessel rim and body has a continuous series of vertical pinched ridges.

PIGMENT USE AND LOCATION ON VESSEL: none

TYPE AND VARIETY (IF KNOWN): Killough Pinched

SITE NAME OR SITE NUMBER: John Braggs (41CE23)

VESSEL NO.: 4, Disturbed burial

VESSEL FORM: Jar

NON-PLASTICS AND PASTE: grog and hematite

RIM AND LIP FORM: Direct rim and rounded lip

CORE COLOR: F (fired in a reducing environment and cooled in the open air)

INTERIOR SURFACE COLOR: yellowish-brown; fire clouds on the rim and body 
EXTERIOR SURFACE COLOR: yellowish-brown; fire clouds on the rim, body, and base; pink fire clouds on the body

WALL THICKNESS (IN MM): rim, $5.7 \mathrm{~mm}$

INTERIOR SURFACE TREATMENT: none

EXTERIOR SURFACE TREATMENT: none

HEIGHT (IN CM): 10.8

ORIFICE DIAMETER (IN CM): 11.4

DIAMETER AT BOTTOM OF RIM OR NECK (IN CM): 11.4

BASE DIAMETER (IN CM) AND SHAPE OF BASE: 7.4; circular and flat

ESTIMATED VOLUME (IN LITERS): 0.74

DECORATION (INCLUDING MOTIF AND ELEMENTS WHEN APPARENT): Vertical brushing marks on the vessel rim and body.

PIGMENT USE AND LOCATION ON VESSEL: none

TYPE AND VARIETY (IF KNOWN): Bullard Brushed

SITE NAME OR SITE NUMBER: John Braggs (41CE23)

VESSEL NO.: 5, Disturbed burial

VESSEL FORM: Jar

NON-PLASTICS AND PASTE: grog

RIM AND LIP FORM: Everted rim and rounded lip

CORE COLOR: $\mathrm{G}$ (fired in a reducing environment and cooled in the open air)

INTERIOR SURFACE COLOR: dark grayish-brown

EXTERIOR SURFACE COLOR: yellowish-brown; fire clouds on the rim, body, and base

WALL THICKNESS (IN MM): rim, $4.1 \mathrm{~mm}$

INTERIOR SURFACE TREATMENT: none

EXTERIOR SURFACE TREATMENT: none

HEIGHT (IN CM): 5.0

ORIFICE DIAMETER (IN CM): 7.1

DIAMETER AT BOTTOM OF RIM OR NECK (IN CM): 6.9 
BASE DIAMETER (IN CM) AND SHAPE OF BASE: 5.7; circular and flat

ESTIMATED VOLUME (IN LITERS): 0.22

DECORATION (INCLUDING MOTIF AND ELEMENTS WHEN APPARENT): The vessel rim has a haphazardly and incompletely executed horizontal incised panel, a small portion of which has diagonal and diagonal opposed incised lines.

PIGMENT USE AND LOCATION ON VESSEL: none

TYPE AND VARIETY (IF KNOWN): Unidentified utility ware

SITE NAME OR SITE NUMBER: John Braggs (41CE23)

VESSEL NO.: 6, Disturbed Burial

VESSEL FORM: Jar

NON-PLASTICS AND PASTE: grog and hematite

RIM AND LIP FORM: Direct rim and rounded, exterior folded lip

CORE COLOR: F (fired in a reducing environment and cooled in the open air)

INTERIOR SURFACE COLOR: yellowish-brown; fire clouds on the rim, body, and base; organic residue on rim and body

EXTERIOR SURFACE COLOR: yellowish-brown; fire clouds on the rim, body, and base; pink fire clouds on the vessel body

WALL THICKNESS (IN MM): rim, $4.8 \mathrm{~mm}$

INTERIOR SURFACE TREATMENT: none

EXTERIOR SURFACE TREATMENT: none

HEIGHT (IN CM): 11.7

ORIFICE DIAMETER (IN CM): 13.5

DIAMETER AT BOTTOM OF RIM OR NECK (IN CM): 11.8

BASE DIAMETER (IN CM) AND SHAPE OF BASE: 8.0; circular and flat

ESTIMATED VOLUME (IN LITERS): 0.95

DECORATION (INCLUDING MOTIF AND ELEMENTS WHEN APPARENT): Plain

PIGMENT USE AND LOCATION ON VESSEL: none

TYPE AND VARIETY (IF KNOWN): Unidentified plain ware 
SITE NAME OR SITE NUMBER: John Braggs (41CE23)

VESSEL NO.: 7, Disturbed Burial

VESSEL FORM: Carinated bowl

NON-PLASTICS AND PASTE: grog and bone

RIM AND LIP FORM: Direct rim and rounded lip

CORE COLOR: Unknown

INTERIOR SURFACE COLOR: reddish-brown; fire clouds on the body and base

EXTERIOR SURFACE COLOR: yellowish-brown; fire clouds on the rim, body, and base

WALL THICKNESS (IN MM): rim, $5.3 \mathrm{~mm}$

INTERIOR SURFACE TREATMENT: smoothed

EXTERIOR SURFACE TREATMENT: burnished

HEIGHT (IN CM): 8.9

ORIFICE DIAMETER (IN CM): 16.4

DIAMETER AT BOTTOM OF RIM OR NECK (IN CM): 16.2

BASE DIAMETER (IN CM) AND SHAPE OF BASE: 7.0; circular and flat

ESTIMATED VOLUME (IN LITERS): 0.88

DECORATION (INCLUDING MOTIF AND ELEMENTS WHEN APPARENT): The rim has three engraved panels of horizontal and vertical interlocking scrolls (Figure 19). Three of the interlocking scrolls have excised triangle elements, or hatched triangle elements, and a fourth has upper and lower rectangular scroll fill elements with a series of narrow vertical excised columns.

PIGMENT USE AND LOCATION ON VESSEL: none

TYPE AND VARIETY (IF KNOWN): Poynor Engraved, var. $B$

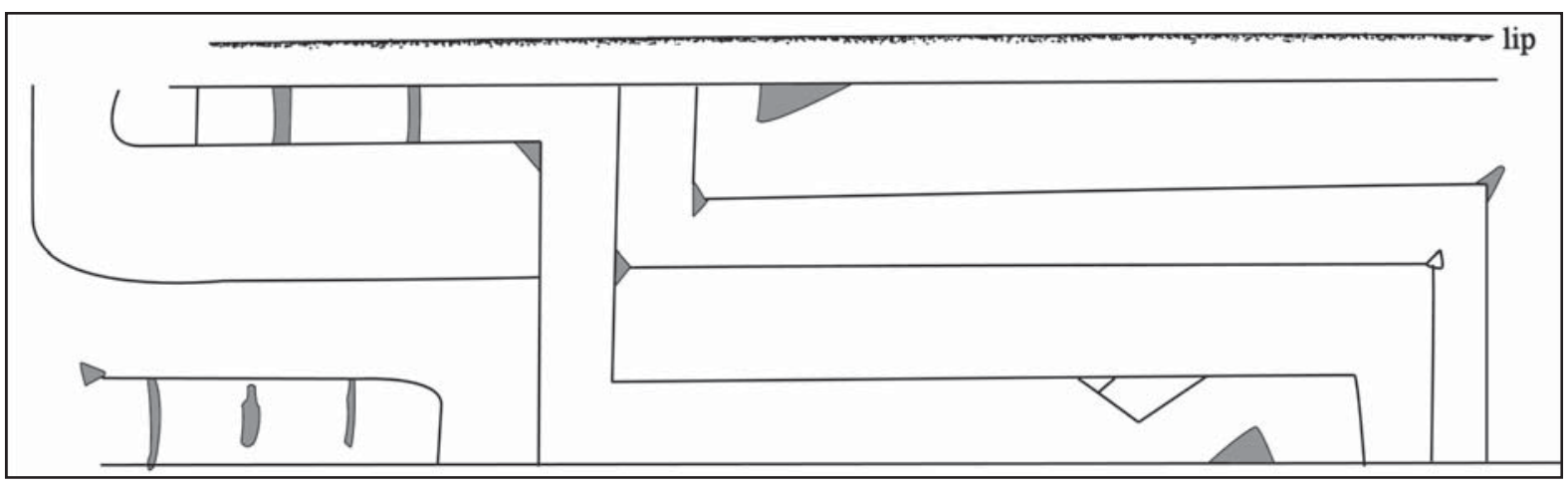

Figure 19. Decorative elements on a Poynor Engraved, var. B carinated bowl (Vessel 7) from the John Braggs site (41CE23). 
SITE NAME OR SITE NUMBER: John Braggs (41CE23)

VESSEL NO.: 11, Disturbed Burial

VESSEL FORM: Jar

NON-PLASTICS AND PASTE: grog

RIM AND LIP FORM: N/A

CORE COLOR: F (fired in a reducing environment and cooled in the open air)

INTERIOR SURFACE COLOR: yellowish-brown; fire clouds on the body and base

EXTERIOR SURFACE COLOR: yellowish-brown; fire clouds on the base

WALL THICKNESS (IN MM): body, $5.3 \mathrm{~mm}$

INTERIOR SURFACE TREATMENT: smoothed

EXTERIOR SURFACE TREATMENT: none

HEIGHT (IN CM): 13.5+

ORIFICE DIAMETER (IN CM): 26.9+

DIAMETER AT BOTTOM OF RIM OR NECK (IN CM): N/A

BASE DIAMETER (IN CM) AND SHAPE OF BASE: 9.0; circular and flat

ESTIMATED VOLUME (IN LITERS): $2.2+$

DECORATION (INCLUDING MOTIF AND ELEMENTS WHEN APPARENT): Horizontal, diagonal, and overlapping brushing marks on the vessel body.

PIGMENT USE AND LOCATION ON VESSEL: none

TYPE AND VARIETY (IF KNOWN): Bullard Brushed

\section{Summary and Conclusions}

Ceramic vessels from six ancestral Caddo sites in the upper Neches River basin in East Texas have been documented in this study, primarily to gain a better understanding of the age and cultural affiliations of the sites and the ceramic artifacts they contained in burial features. The sites include Ballard Estate (41AN53), O. L. Ellis (41AN54), Lee Ellis (41AN56), Dabbs Estate (41AN57), A. H. Reagor (41CE15), and John Braggs (41CE23); the vessels from these sites were collected in the 1930s by University of Texas archaeologists.

These vessels are from a post-A.D. 1400 community of Caddo ceramic practice, a community where similar vessel forms (of small to moderate volume) were made (including jars, bowls, bottles, carinated bowls, and effigy bowl) primarily with grog temper, fired in a low oxygen or reducing environment and cooled in the open air, and decorated with either wet paste (i.e., utility ware vessels decorated with 
brushed, incised, pinched, or punctated elements) or hard paste (i.e., fine ware) engraved elements. There is a common set of shared ceramic types and varieties in the six sites as an assemblage, including Bullard Brushed, Killough Pinched, and Maydelle Incised utility wares (Table 1), and Hood Engraved, Patton Engraved, and Poynor Engraved types. Single varieties are represented in the Hood Engraved and Patton Engraved vessels from the O. L. Ellis and A. H. Reagor sites, while there are six recognized varieties of Poynor Engraved in the sites, with Poynor Engraved, var. Hood the best represented fine ware variety.

Table 1. Identified ceramic types in the six Upper Neches River basin sites in Anderson and Cherokee counties, Texas.

\begin{tabular}{|c|c|c|c|c|c|c|}
\hline \multirow[t]{2}{*}{ Type-variety } & \multicolumn{6}{|c|}{ Sites } \\
\hline & AN53 & AN54 & AN56 & AN57 & CE15 & CE23 \\
\hline \multicolumn{7}{|l|}{ Utility ware } \\
\hline Bullard Brushed & & $\mathrm{X}$ & $\mathrm{X}$ & & $\mathrm{X}$ & $\mathrm{X}$ \\
\hline Killough Pinched & & $\mathrm{X}$ & & & & $X$ \\
\hline Maydelle Incised & & $\mathrm{X}$ & & & & $\mathrm{X}$ \\
\hline \multicolumn{7}{|l|}{ Fine ware } \\
\hline Hood Engraved, var. Allen & & $\mathrm{X}$ & & & & \\
\hline Patton Engraved, var. Allen & & $X$ & & & $\mathrm{X}$ & \\
\hline Poynor Engraved, var. Blackburn & $\mathrm{X}$ & & & & $\mathrm{X}$ & \\
\hline Poynor Engraved, var. Freeman & & $\mathrm{X}$ & & & & \\
\hline Poynor Engraved, var. Hood & & $\mathrm{X}$ & & & & $\mathrm{X}$ \\
\hline Poynor Engraved, var. $B$ & & & & & & $\mathrm{X}$ \\
\hline Poynor Engraved, var. $N^{\prime}$ & $\mathrm{X}$ & & & & & \\
\hline Poynor Engraved, var. $N-1$ & & $\mathrm{X}$ & & & & \\
\hline Poynor Engraved, unspecified & $\mathrm{X}$ & $\mathrm{X}$ & & $\mathrm{X}$ & & \\
\hline
\end{tabular}

The occurrence of the different fine ware types and varieties in this group of six ancestral Caddo sites in the upper Neches River basin indicate that burial features at the sites date from the early $15^{\text {th }}$ century A.D., in the beginning of the Late Caddo period Frankston phase, to the late $17^{\text {th }}$-early $18^{\text {th }}$ century, in the Historic Caddo Allen phase (see Perttula 2011:Table 6-37); it also appears to be the case that the cemeteries at these sites were used during several different time periods, not in one continuous period of burial interment. Specifically, the ceramic vessels from the John Braggs site (41CE23) suggest its use as a cemetery from ca. A.D. 1400-1560, while the ceramic vessels from the Ballard Estate site (41AN53) suggest its use as a cemetery from ca. A.D. 1480-1680; the Lee Ellis (41AN56) and Dabbs Estate (41AN57) sites were used as a cemetery during an unknown part of the Frankston phase (ca.A.D. 1400-1680). In the case of the O. L. Ellis site (41AN54), the vessels present suggest that burials were interred in a cemetery there primarily between ca. A.D. 1480-1560 (when Poynor Engraved, var. Hood most commonly occur in Frankston phase cemeteries), but continued to be used from ca. A.D. 1560-1680 and from ca. A.D. 1680-1720. The vessels from the A. H. Reagor site (41CE15) are indicative of cemetery use from ca. A.D. 1480-1560 and ca. A.D. 1680-1720.

Lastly, a number of the vessels from these upper Neches River basin sites are identified as coming from "pinkware" vessels (see Perttula 2011:206-209), including 50 percent of the vessels from the Ballard Estates site (41AN53), 26.7 percent of the vessels from the O. L. Ellis site (41AN54), and 50 percent of the vessels from the John Braggs site (41CE23). These pinkware are vessels and sherds with a distinctive red $(10 \mathrm{R} 5 / 8)$ paste after firing. These vessels were made with a clay with a moderate to high iron content (cf. Cordell 2001:17). Although the source of this clay is not known, it likely derives locally from 
iron-rich Weches Formation outcrops in the southwestern part of Smith County, the northwestern part of Cherokee County, and northeastern Anderson County (see Bureau of Economic Geology 1965) (see Perttula 2011:Figure 6-19).

Pinkware vessels and vessel sherds have been documented in a number of other post-A.D. 1400 Caddo ceramic assemblages in the upper Neches River basin, as well as a few sites downstream in the middle Neches River basin. In the latter area, this includes a few sherds from the R. F. Wallace site (41CE20) and 41CE47; these may be from vessels that were made in the upper Neches River basin. In the upper Neches River basin itself, pinkware is present in the sherd assemblages from the Isibel-Gene Donnell site (41AN14, 8 percent of the sherds), the Solon Stanley site (41CE3, 8.3 percent), the Lang Pasture site (41AN38, 7.8 percent), and the J. W. Blackburn (41CE4, 1.4 percent) site. Furthermore, a number of pinkware vessels have been identified from prehistoric cemeteries in the upper Neches River basin. Approximately 11.2 percent of the 277 vessels from the Mrs. J. M. Cook (41AN1), Mr. J. M. Cook (41AN2), Fred McKee (41AN32), J. W. Blackburn (41CE4), Omer and Otis Hood (41Ce14), E. W. Henry (41CE17), and R. J. Fair (41CE25) sites have the distinctive iron-rich pinkware paste. This iron-rich clay was used to manufacture both utility ware (i.e., Bullard Brushed, Killough Pinched) and fine ware vessels (Hood Engraved effigy vessels, Hume Engraved, Poynor Engraved), as well as plain bottles and carinated bowls (Perttula 2011:207). The highest proportion of pinkware vessels have been documented at the Fred McKee and J. W. Blackburn sites (Table 2), in contexts dating between ca. A.D. 1480-1680. These sites-perhaps closer to the ultimate source of an iron-rich clay used by ancestral Caddo potters - are in the same general locale as the six upper Neches River basin sites discussed in this article.

Table 2. Pinkware vessels from selected Caddo sites in the upper Neches River Basin.

\begin{tabular}{|c|c|c|c|}
\hline Site & $\begin{array}{l}\text { No. of } \\
\text { Vessels }\end{array}$ & $\begin{array}{l}\text { Proportion of } \\
\text { Pinkware Vessels }(\%)\end{array}$ & Types Represented \\
\hline 41AN1 & 33 & 12.1 & $\begin{array}{l}\text { Poynor Engraved, var. Lang; Hood } \\
\text { Engraved; Killough Pinched }(\mathrm{n}=2)\end{array}$ \\
\hline 41AN2 & 17 & 11.8 & $\begin{array}{l}\text { Poynor Engraved, var. T; Bullard } \\
\text { Brushed }\end{array}$ \\
\hline 41AN32 & 23 & 39.1 & $\begin{array}{l}\text { Plain bottle; Poynor Engraved, var. } P \text {; } \\
\text { Poynor Engraved, var. Freeman }(\mathrm{n}=2) \text {; } \\
\text { Poynor Plain; Poynor Engraved, var. } \\
\text { Cook; Brushed-punctated jar }(\mathrm{n}=2) ; \\
\text { Hume Engraved }\end{array}$ \\
\hline $41 \mathrm{CE} 4$ & 24 & 20.8 & $\begin{array}{l}\text { Poynor Engraved, var. Hood }(\mathrm{n}=2) ; \\
\text { Hume Engraved }(\mathrm{n}=2) ; \text { Hood Engraved }\end{array}$ \\
\hline 41CE14 & 118 & 3.4 & $\begin{array}{l}\text { Poynor Engraved, var. K; Poynor } \\
\text { Engraved, var. Blackburn; Hood } \\
\text { Engraved; Killough Pinched; Poynor } \\
\text { Engraved bottle }\end{array}$ \\
\hline 41CE17 & 35 & 8.6 & $\begin{array}{l}\text { Collared bottle; effigy vessel; Poynor } \\
\text { Engraved, var. } B\end{array}$ \\
\hline 41CE25 & 27 & 11.1 & $\begin{array}{l}\text { Poynor Engraved, var. Freeman; Poynor } \\
\text { Engraved, var. Hood }(\mathrm{n}=2)\end{array}$ \\
\hline
\end{tabular}




\section{Acknowledgments}

We thank the staff at the Texas Archeological Research Laboratory at The University of Texas at Austin for access to these vessel collections for documentation purposes, especially Marybeth Tomka and Jonathan Jarvis. Lance Trask prepared the figures in this article.

\section{References Cited}

Bureau of Economic Geology

1965 Geologic Atlas of Texas: Tyler Sheet. Bureau of Economic Geology, The University of Texas at Austin.

Collar, A., F. Coward, T. Brughmans, and B. J. Mills

2015 Networks in Archaeology: Phenomena, Abstraction, Representation. Journal of Archaeological Method and Theory 22:1-32.

Cordell, A. S.

2001 Continuity and Change in Apalachee Pottery Manufacture: A Technological Comparison of ApalacheeStyle and Colono Ware Pottery from French Colonial Old Mobile and Mission San Luis de Talimali. Archaeological Monographs No. 9. Center for Archaeological Studies, University of South Alabama, Mobile.

Hart, J. P.

2016 Networking the Past. Paper presented at the $58^{\text {th }}$ Caddo Conference, Nacogdoches, Texas.

Mills, B. J., M. A. Peeples, W. R. Haas, Jr., L. Borck, J. J. Clark, and J. M. Roberts, Jr.

2015 Multiscalar Perspectives on Social Networks in the Late Prehispanic Southwest. American Antiquity 80(1):3-24.

Peeples, M. A. and J. M. Roberts Jr.

2013 To binarize or not to binarize: relational data and the construction of archaeological networks. Journal of Archaeological Science 40:3001-3010.

Perttula, T. K.

2011 The Ceramic Artifacts from the Lang Pasture Site (41AN38) and the Place of the Site within an Upper Neches River Basin Caddo Ceramic Tradition. In Archeological Investigations at the Lang Pasture Site (41AN38) in the Upper Neches River Basin of East Texas, assembled and edited by T. K. Perttula, D. B. Kelley, and R. A. Ricklis, pp. 145-320. Archeological Studies Program Report No. 129, Texas Department of Transportation, Environmental Affairs Division, Austin.

Perttula, T. K., D. B. Kelley, and R. A. Ricklis (assemblers and editors)

2011 Archeological Investigations at the Lang Pasture Site (41AN38) in the Upper Neches River Basin of East Texas. Report No. 129. Texas Department of Transportation, Archeological Studies Program, Environmental Affairs Division, Austin.

Selden, R. Z. Jr., T. K. Perttula, and D. L. Carlson

2014 INAA and the provenance of shell-tempered sherds in the ancestral Caddo region. Journal of Archaeological Science 47:113-120.

Smith, N. G., A. Karasik, T. Narayanan, E. S. Olson, U. Smilanksy, and T. E. Levy

2014 The Pottery Informatics Query Database: A New Method for Mathematic and Quantitative Analyses of Large Regional Ceramic Datasets. Journal of Archaeological Method and Theory 21(1):212-250.

Suhm, D. A. and E. B. Jelks (editors)

1962 Handbook of Texas Archeology: Type Descriptions. Special Publication No. 1, Texas Archeological Society, and Bulletin No. 4, Texas Memorial Museum, Austin. Reprinted in 2009, Gustav's Library, Davenport, Iowa. 